\title{
El Llibre de cetreria del vescomte de Rocabertí
}

\section{The Llibre de cetreria [Book of falconry] by the viscount of Rocabertí}

\author{
RicARdo M. Olmos DE LEÓN \\ olmosdeleon@gmail.com \\ Investigador independent
}

Carmel Ferragud carmel.ferragud@uv.es

Institut Interuniversitari López Piñero - UV

\begin{abstract}
Resum: En el present article oferim una edició crítica del Llibre de cetreria, un breu tractat de falconeria escrit en català i conservat en manuscrit únic pertanyent a una collecció privada. També n'estudiem l'estructura i el contingut, a més de les relacions amb altres obres de falconeria, especialment les escrites a la Corona d'Aragó. Oferim una hipòtesi sobre la identificació del seu autor i l'època de la composició del tractat. Com que es tracta de l'obra escrita en català que major nombre d'ocells de caça esmenta, a la present edició ens ha semblant oportú de fer una exposició detallada de les aus emprades pels caçadors, com també tota la terminologia que la llengua catalana va desenvolupar per a referir-s'hi.
\end{abstract}

Paraules clau: falconeria, caça, noblesa, Corona d’Aragó, ocells de presa

Abstract: In this article we offer a critical edition of Llibre de cetreria [Book of falconry], a brief treatise of falconry written in Catalan. It is kept as a sole manuscript belonging to a private collection. We study its structure and content, as well as its relations with other falconry archive teatrises, namely those written in the Crown of Aragon. We formulate a hypothesis about the authorship and the age when the treatise was written. This is the Catalan treatise naming the greatest number of birds of prey. Hence, in this edition we offer a thorough exposition of the birds used by hunters, and the related terminology that was developed in Catalan.

Key words: falconry, hunting, nobility, Crown of Aragon, birds of prey

\footnotetext{
* Aquest treball s'inscriu en el marc del Projecte d'Investigació subvencionat per la Generalitat Valenciana «La falconeria a la Corona d'Aragó durant la baixa edat mitjana: edició crítica de textos i estudi de documentació arxivística» (AICO/2019/255).
} 


\section{Ricardo M. Olmos de León \& Carmel Ferragud. El Llibre de cetreria del vescomte}

de Rocabertí

\section{Introducció}

El Llibre de cetreria és un breu tractat de falconeria escrit en català i conservat en manuscrit únic pertanyent a una col-lecció privada. El 1951, el seu propietari en va proporcionar una edició facsímil, però únicament s'hi donava compte de les vicissituds de la seua obtenció en una subhasta i no anava acompanyada de cap transcripció ni estudi del contingut (Rocabertí 1951). Gràcies a aquest facsímil, però, diversos estudiosos han pogut aproximar-se al contingut del manuscrit. Malgrat que Trias de Bes (1996), en una conferència celebrada a la Reial Acadèmia de Bones Lletres de Barcelona, atribuïa tot el text al vescomte de Rocabertí, estudis posteriors han posat de manifest que el còdex reunia en realitat dues obres diferents i que el vescomte va ser autor únicament de la primera. Poc abans, també el professor Fradejas (1993) considerava tot el text del manuscrit com una obra única i l'atribuïa al vescomte. De la segona, anònima però atribuïda de forma fictícia al rei Artús, ja comptem amb una edició crítica realitzada per Mas / Garcia (2013) amb el títol de Tractat per l'art de la caça, a la qual remetem per a una descripció del manuscrit. Assenyalem ací que, tot i que l'esmentat Trias de Bes plantejava la possibilitat que el manuscrit conservat fora l'original autògraf del vescomte, nombrosos errors de còpia evidents -fins $i$ tot potser la pèrdua de fragments o seccions completes que es pot intuir amb la lectura-, $\mathrm{i}$ alguns italianismes suggereixen, com ja ha estat proposat anteriorment (Cifuentes 2021b; Mas / Garcia 2013: 98-99, 109-11), que es tracta d'una còpia realitzada a la fi del segle XV o inici del XVI a Itàlia, potser a la cort napolitana dels reis aragonesos. A més a més, la primera de les obres del manuscrit, la pròpiament composta pel vescomte de Rocabertí amb el títol de Llibre de cetreria, ja fou objecte d'una edició crítica per part de Querol (2004). No obstant això, el fet que aquest estudi no s'arribara a publicar, juntament amb les dificultats per a accedir-hi, ens han portat a realitzar una nova edició del text, de manera que el seu contingut estiga a l'abast per a futures investigacions sobre la falconeria medieval.

El tractat del vescomte de Rocabertí presenta algunes característiques que el fan especialment valuós per a l'estudi d'aquesta activitat venatòria en el context de la Corona d'Aragó. Es tracta d'un dels pocs tractats conservats escrits originàriament en llengua catalana i per un autor conegut. A més, malgrat que, com veurem, va poder comptar amb algunes fonts, tot suggereix que el contingut reflecteix el coneixement i la pràctica de l'autor o, almenys, dels caçadors de la seua època. Aquest fet, sens dubte, atorga un enorme valor a l'obra per a la investigació de la falconeria a la Corona d'Aragó, ja que el distingeix de les traduccions catalanes de tractats llatins, que sovint mostren una relació menys estreta amb la pràctica real dels caçadors dels segles XIV i $\mathrm{XV}$, quan no dubtosa. ${ }^{1}$

Un altre aspecte de l'obra de Rocabertí de gran interés és la descripció que conté dels ocells de caça, ja que es tracta de la que realitza un caçador en la seua pròpia llengua. De fet, on més fàcilment es constata l'estreta correspondència entre la informació continguda en el nostre text i la pràctica real dels caçadors és en els

1 Per a una visió de conjunt de les obres de falconeria escrites en català, vegeu Cifuentes (2006: 151-156), Querol (2003: 6-9; 2005: 140-143; 2018: 49-53) i Fradejas (2008: 15-20).

SCRIPTA, Revista internacional de literatura i cultura medieval i moderna, núm. 17 / juny 2021 / pp. 237-279 ISSN: 2340-4841· doi:10.7203/SCRIPTA.17.209914 
noms dels ocells que utilitzaven, ja que, com veurem, les aus descrites en l'obra del vescomte concorden perfectament amb les que apareixen recollides en nombrosíssims documents d'arxiu dels segles XIV i $\mathrm{XV}$. Altres tractats catalans de falconeria, per contra, o bé no tenen una secció dedicada a la descripció d'aquests animals de caça, o bé són traduccions en les quals els termes emprats per a referir-se a les aus poc tenen a veure amb els emprats pels caçadors de llengua catalana de la baixa edat mitjana i el Renaixement. El Llibre de caça, una de les obres catalanes més completes que s'han conservat, tan sols ens ofereix en els capítols inicials la descripció d'astors i esparvers, però no de les diverses espècies de falcons; potser aquesta part es trobava en els primers folis del manuscrit únic en què es conserva l'obra i que s'han perdut.

En aquest treball ens proposem de fer una edició crítica del tractat del vescomte; l'acompanyem amb una breu notícia sobre l'autor -i, com a conseqüència, de la data aproximada de composiciói també d'altres personalitats esmentades en l'obra. També n'oferim una anàlisi de l'estructura i el contingut $i$ de les relacions amb altres obres de falconeria, especialment les escrites en la Corona d'Aragó. Com que es tracta de l'obra escrita en català que major nombre d'ocells de caça esmenta, hem elaborat una exposició detallada dels ocells de presa més habituals, així com tota la terminologia que la llengua catalana va desenvolupar per a denominar-los.

\section{L'autor, el promotor, el destinatari i la data de composició}

L'autor del text es declara explícitament vescomte de Rocabertí. Però, quina d'entre totes les persones que tingueren aquest títol va escriure el Llibre de cetreria? En el tractat es fa referència, a més, a altres dos personatges que poden ajudar a la identificació de l'autor: el promotor, Pedro d'Essa, i el destinatari, el cardenal de València, del qual no es diu el nom. Aquesta informació, juntament amb la datació aproximada que poguera proporcionar la relació amb altres textos, hauria de facilitar la identificació precisa del vescomte. No obstant això, com veurem en l'apartat següent, les relacions amb altres tractats de falconeria amb prou feines ens permeten precisar un interval en el qual situar la composició del Llibre de cetreria. Si, com suggerim més endavant, l'autor de l'obra va tenir com a model el tractat de falconeria del canceller Pero López de Ayala, l'any de composició d'aquesta obra, 1386, suposaria un terme post quem per a la redacció del nostre text.

Trias de Bes (1996: 27-30) va proposar com a autor del Llibre de cetreria a «Martí Onofre de Rocabertí y de Rocabertí (m. en 1567), vigésimo segundo Vescomte de Rocabertí, que lo fue desde 1512, año en que falleció su padre Felip Dalmau II». Aquesta proposta es basa en la identificació de l'inductor de l'obra, «don Pedro d'Essa», que Trias identifica amb Pedro de Deza, un personatge nascut a Sevilla en 1520 i mort a Roma en 1600, després d'assolir una alta notorietat eclesiàstica i política. Per la seua banda, Querol (2005: 141; 2018: 51) avançà la composició del tractat al segle XIV (entre 1387 i 1392), i va identificar-ne l'autor amb Felip Dalmau de Rocabertí i Montcada (†1392). ${ }^{2}$

\footnotetext{
2 Aquest investigador ofereix un estudi detallat sobre el vescomte, en el qual el proposa com a autor del Llibre de cetreria a <http://dbe.rah.es/biografias/64320/felip-dalmau-de-rocaberti-y-montcada>.
}

SCRIPTA, Revista internacional de literatura i cultura medieval i moderna, núm. 17 / juny 2021 / pp. 237-279 ISSN: 2340-4841· doi:10.7203/SCRIPTA.17.209914 
Per la nostra banda, considerem que les dues propostes podrien haver errat en la identificació de l'autor del nostre tractat. Nosaltres ens inclinem per situar la composició al segle XV. D'una banda, la major part de les obres amb les quals es pot relacionar el contingut del Llibre de cetreria se situen, de manera precisa o aproximada, en la segona meitat del segle XV i principis del XVI. La majoria dels remeis proposats pel vescomte semblen ser els que estaven en ús en el període esmentat. En suport d'aquesta hipòtesi de partida també estaria el fet que alguns termes, aparentment castellanismes, es coneixien en l'àmbit de la Corona d'Aragó des de mitjans de segle XV. Tal és el cas del terme emprat en el títol, cetreria, que trobem també en l'Espill (c. 1460) de Jaume Roig (Roig 2014: v. 991) o en el títol de l'obra del cavaller calabrés Alfonso Caracciolo, Hopera de citraria, escrita entre 1495 i 1507. També el terme tagarot, que el nostre autor utilitza per a referir-se a l'espècie de falcó que en la documentació del segle XIV es denomina (munteri) barbaresc, el trobem en obres de la segona meitat del segle XV, com ara el Libro de piaceri e doctrina de li uccelli, de Lluís de Besalú i Giovanni Pietro Belbasso. ${ }^{3}$

Aquestes sospites, basades en el contingut i la terminologia, ens condueixen a donar suport a la proposta de Cifuentes (2021b), que considera que l'autor del Llibre de cetreria es Jofré (VII) de Rocabertí (c. 1420-1479). Cifuentes es basa en la identificació que Querol havia fet de l'inductor de l'obra, Pedro de Eza (Pere d'Essa o Pedro d'Eça). Aquest cavaller castellà fou un dels principals capitans de Pere IV el Conestable de Portugal (1429-1466), juntament amb Jofre de Rocabertí, que lluitaren en la guerra contra Joan II el Sense Fe. Tots dos, juntament amb Bernat Gilabert de Cruilles i Guillem Alemany de Cervelló, foren capturats en la batalla de Calaf (o dels Prats de Rei), el 7 de març de 1465, i el 9 d'agost ingressaren en la presó de Xàtiva, esdeveniment que va ser narrat per Melcior Miralles en la seua crònica (2011: 370). El castellà fou alliberat el 1468, però el vescomte, per la seua rellevància política, no ho fou fins uns anys després, $\mathrm{i}$ tot seguit hagué de recongraciar-se amb el rei per tal de recuperar el seu patrimoni. Cifuentes (2021a) ha elaborat una suggerent hipòtesi que lliga ambdós nobles amb la tercera personalitat mencionada en l'obra, el cardenal de València des de 1456, Roderic de Borja (Xàtiva, 1431-Roma, 1503), futur Alexandre VI, papa entre 1492 i 1503. El cardenal, destinatari de l'obra, viatjà a València i a Castella vers 1472 com a legat papal per a promoure la croada contra els turcs i hi portà la butla de dispensa que legalitzà el matrimoni del llavors príncep de Girona, Ferran II, amb Isabel de Castella. És probable que l’obra, suggerida per Pedro de Eza, buscara el perdó del rei al vescomte, aprofitant el viatge i la influència del cardenal Borja. El prelat era segurament tan aficionat a la falconeria com els estaments nobiliaris i també els membres de l'alta jerarquia eclesiàstica, i degué pensar que una obra de tals característiques seria rebuda de molt bon grat.

Així doncs, la identificació de tots tres personatges, les relacions entre ells i els episodis particulars en les seues vides porten Cifuentes (2021b) a situar la composició del tractat que ací editem entre 1465 i 1473, el que ens sembla perfectament compatible amb les relacions que hem trobat amb altres textos de falconeria del segle XV.

3 Libro de piaceri e doctrina de li uccelli, Biblioteca Trivulziana (Milà), ms. 2141, f. 40r.

SCRIPTA, Revista internacional de literatura i cultura medieval i moderna, núm. 17 / juny 2021 / pp. 237-279 ISSN: 2340-4841· doi:10.7203/SCRIPTA.17.209914 


\section{Ricardo M. Olmos de León \& Carmel Ferragud. El Llibre de cetreria del vescomte} de Rocabertí

\section{El contingut del Llibre de cetreria i la seua relació amb altres tractats de falconeria}

El manuscrit conservat de l'obra del vescomte no conté rúbriques ni divisions en capítols, malgrat que el seu contingut està ben organitzat i presenta una estructura clara que el divideix, en termes generals, en una primera part dedicada a la descripció dels ocells de caça, i que hi inclou alguna instrucció sobre el seu ensinistrament, i una segona part dedicada a les cures, en la qual es recullen també les prescripcions relacionades amb la muda de les aus. L'estructura i contingut de l'obra s'allunya sensiblement de la pauta habitual en els tractats de falconeria escrits a la Corona d'Aragó -tant en català com en italià-, ja que aquests es dediquen essencialment als aspectes mèdics $\mathrm{i}$ rarament inclouen informacions ornitològiques $\mathrm{i}$ cinegètiques, o bé aquestes són mínimes. ${ }^{4}$ No obstant això, hi ha excepcions significatives a aquesta tesi -el Llibre de caça, l'Hopera de citraria i el Libro de piaceri e doctrina de li uccelli-, per la qual cosa seria necessari un estudi exhaustiu i de conjunt dels tractats de falconeria escrits a la Corona d'Aragó per a poder arribar a conclusions sòlides.

Tot i la brevetat del text, l'autor s'ocupa pràcticament de tots els continguts que altres tractats contemporanis fora de l'àmbit de la Corona d'Aragó podien atendre, i, de fet, en aquesta diversitat de continguts la nostra obra s'aproxima a la tradició castellana. Efectivament, en les obres castellanes de falconeria, el professor Fradejas (1998: 8-9) distingeix cinc aspectes entre els seus continguts: informacions ornitològiques, informacions cinegètiques, règim higiènic, informació veterinària i informació miscel-lània. Excepte el darrer, tots els altres continguts tenen, en major o menor mesura, cabuda en l'obra del vescomte, malgrat que aquestes informacions no sempre s'hi ofereixen de forma separada, sinó que es troben entrellaçades les unes amb les altres. En aquest sentit, resulta molt cridanera la gran semblança en l'estructura i els temes tractats entre el Llibre de cetreria de Rocabertí i el Libro de la caza de las aves del canceller Pero López de Ayala -malgrat l'enorme diferència en extensió entre ambdues-, per la qual cosa podríem preguntarnos si Rocabertí tingué com a model formal l'obra d'Ayala. Que un autor s'inspire en un altre escrit o l'adopte com a referent per a algun aspecte concret, però no per traslladar directament els seus continguts, no és una cosa aliena al camp de la literatura falconera. Així, s'ha pogut demostrar que Juan Manuel es va inspirar en el De arte venandi cum avibus de Frederic II per a la composició del seu Libro de la caza, tot i que els continguts pròpiament dits d'aquesta obra van poder ser en gran part originals (Fradejas 2005), malgrat l'enorme diferència d'extensió entre ambdós tractats.

Vegem alguns paral-lelismes entre el Llibre de cetreria i el Libro de la caza de las aves. ${ }^{5}$ Ambdues obres s'inicien amb una invocació, la declaració de l'autoria, una dedicatòria i una exposició dels motius per a la composició, passatges en els quals fins i tot es fan servir fórmules molt semblants:

\footnotetext{
4 Per a completar la visió general dels tractats de falconeria relacionats amb la Corona d'Aragó és necessari prendre en consideració els que han estat escrits en italià, per a això remetem a Lupis (1975) i Lupis / Panunzio (1992).
}

5 Per al Libro de la caza de las aves seguim l'edició de Delgado (2007).

SCRIPTA, Revista internacional de literatura i cultura medieval i moderna, núm. 17 / juny 2021 / pp. 237-279 ISSN: 2340-4841· doi:10.7203/SCRIPTA.17.209914 


\begin{tabular}{|c|c|}
\hline $\begin{array}{l}\text { Ayala, Libro de la caza de las aves } \\
\text { (pp. 59-63) }\end{array}$ & $\begin{array}{l}\text { Rocabertí, Llibre de cetreria } \\
\text { (f. } 1 \mathrm{r})\end{array}$ \\
\hline \multicolumn{2}{|c|}{ Invocació } \\
\hline $\begin{array}{l}\text { En el nombre del Padre e del Fijo e del Espíritu Santo } \\
\text { (p. 59) }\end{array}$ & En nom de Déu et de la sua beneyta mare la verge Marya \\
\hline \multicolumn{2}{|c|}{ Atribució d'autoria } \\
\hline començaré una pequeña obra ...(p. 59) & (...) comens lo present tractat fet per mi, (...) \\
\hline \multicolumn{2}{|c|}{ Dedicatòria } \\
\hline $\begin{array}{l}\text { Al muy honrado padre e señor don Gonçalo de Mena } \\
\text { por la graçia de Dios obispo de la muy noble çibdat de } \\
\text { Burgos. (p. } 60 \text { ) }\end{array}$ & $\begin{array}{l}\text { (...) per lo reverendissimo senyor, lo senyor cardenal de } \\
\text { València. }\end{array}$ \\
\hline \multicolumn{2}{|c|}{ Motivació } \\
\hline $\begin{array}{l}\text { (...) e por esto acordé de trabajar por non estar oçioso de } \\
\text { poner en este pequeño libro (...) (p. 63) }\end{array}$ & (...) a prechs de don Pedro d'Essa \\
\hline
\end{tabular}

A continuació, ambdós autors aclareixen quin serà el contingut de les seues obres:

\begin{tabular}{|l|l|}
\hline \multicolumn{1}{|c|}{$\begin{array}{c}\text { Ayala, Libro de la caza de las aves } \\
\text { (p. 60) }\end{array}$} & \multicolumn{1}{|c|}{$\begin{array}{c}\text { Rocabertí, Llibre de cetreria } \\
\text { (f. 1r) }\end{array}$} \\
\hline \multicolumn{2}{|c|}{ Descripció de l'obra } \\
\hline $\begin{array}{l}\text { La qual obra será un pequeño escripto en que departirá } \\
\text { de la caça de las aves e de sus plumages e dolençias e } \\
\text { amelezinamientos }\end{array}$ & $\begin{array}{l}\text { La present ordinatió és per l'art de la casa e de tota } \\
\text { natura o agres de falcons, ni qual qualitat tenen, ni com } \\
\text { los de hom tractar ni donar a mengar (...) }\end{array}$ \\
\hline
\end{tabular}

Després de la introducció, ja en el contingut pròpiament dit, ambdues obres dediquen la primera secció a la descripció dels ocells de caça, en concret als falcons. Hi ha una correspondència exacta entre els esmentats en una i l'altra obra, fins i tot en la seua apreciació i valoració, i es qualifiquen com falcons vil.lans el grifalt (cast. girifalte), el sacre, el provençal (cast. borni) i el tunicenc (cast. alfaneque), i es reserven els qualificatius positius (genti) per al pelegrí, el munterí i el tagarot: 


\begin{tabular}{|c|c|}
\hline Ayala, Libro de la caza de las aves & $\begin{array}{c}\text { Rocabertí, Llibre de cetreria } \\
\text { (ff. } 1 \mathrm{v}-4 \mathrm{v})\end{array}$ \\
\hline \multicolumn{2}{|c|}{ Els ocells de caça } \\
\hline $\begin{array}{l}\text { De los plumages de los falcones e primeramente del } \\
\text { falcon neblí (...) e en sus talles son más gentiles ... (p. 89) }\end{array}$ & $\begin{array}{l}\text { Primo comensaré en los falquons pelegrins (...) et de la } \\
\text { gentill qualitat e condició que tenen ... (f. 1v) }\end{array}$ \\
\hline Del falcon baharí e tagarote (p. 109) & $\begin{array}{l}\text { Segonament (...) taguarots. (f. 2r) } \\
\text { Terserament (...) montarins }\end{array}$ \\
\hline Del falcon girifalte (p. 117) & Quartament (...) falquons grifalts (f. $2 \mathrm{v}$ ) \\
\hline Del falcón sacre (p. 127) & Sisenament (...) falcons sacres (f. 4r) \\
\hline Del falcón borní (p. 133) & Vuitenament (...) dels falquons proençals (f. 4v) \\
\hline Del falcón alfaneque (p. 143) & Septenament (...) falcons tunicenchs (f. 4r) \\
\hline ...entrecelís (p. 144) & Quintament (...) bastars (f. 3v) \\
\hline $\begin{array}{l}\text { girifalte (...), sacre e al borní e al alfaneque (...) dizen que } \\
\text { son villanos (p. 90) }\end{array}$ & $\begin{array}{l}\text { Lo falcó grifalt és (...) de qualitat de falcó vilà, que lo qui } \\
\text { fa, fa per fam (...) falcons sacres, qui són dits falcons } \\
\text { villans, com los proençals (...) falcons tunicenchs (...) } \\
\text { tot lo que fan, fan per fam. (ff. } 2 \mathrm{v}-4 \mathrm{v} \text { ) }\end{array}$ \\
\hline
\end{tabular}

A continuació, les dues obres es refereixen a l'ensinistrament del pelegrí (cast. nebli), tot i l'enorme diferència d'extensió entre les dues obres, un ampli i detallat capítol en la del canceller en comparació amb unes poques línies a la del vescomte:

\begin{tabular}{|l|l|}
\hline $\begin{array}{l}\text { Ayala, Libro de la caza de las aves } \\
\text { (p. 149) }\end{array}$ & \multicolumn{1}{|c|}{$\begin{array}{c}\text { Rocabertí, Llibre de cetreria } \\
\text { (f. 5r) }\end{array}$} \\
\hline \multicolumn{1}{|c|}{ Afaitat } \\
\hline $\begin{array}{l}\text { Cómo se deve governar e regir el falcón neblí e çiertas } \\
\text { reglas de plática para ello }\end{array}$ & $\begin{array}{l}\text { Ara primerament vos diré del falquó pelegrin, com } \\
\text { aquell que és més merixedor. }\end{array}$ \\
\hline
\end{tabular}

Els consells que ambdues obres proposen per al maneig i ensinistrament del falcó pelegrí coincideixen a recomanar portar sempre una gallina, així com donar-la a degollar al falcó al lloure, especialment a l'inici de l'ensinistrament:

\begin{tabular}{|c|l|}
\hline Ayala, Libro de la caza de las aves & \multicolumn{1}{|c|}{ Rocabertí, Llibre de cetreria } \\
\hline $\begin{array}{l}\text { Otrosí, véngate sienpre en miente que el día que el neblí } \\
\text { nasçió para tomarlo omen e caçar con él ese día nasçió } \\
\text { la gallina e sienpre la trae contigo biva (p. 188) }\end{array}$ & may del carner .... (f. 5r) \\
\hline
\end{tabular}




\begin{tabular}{|l|l|}
\hline $\begin{array}{l}\text { Otrosí después que vieres que ya viene bien al señuelo, } \\
\text { llámalo a la tira sin cordel, arredrado de villa e de monte } \\
\text { e dale algunas gallinas a degollar en el señuelo... (p. 167) }\end{array}$ & $\begin{array}{l}\text { fou-li degolar tostemps sobre.l loure la gallina o poll, } \\
\text { e ab asò prendrà amor en lo loure, e axí el fareu bon } \\
\text { lourier (...) (f. 5r) }\end{array}$ \\
\hline
\end{tabular}

Després de la descripció de les aus i les instruccions per al seu ensinistrament, ambdues obres prossegueixen amb una secció dedicada a les malalties i hi proposen remeis per a cadascuna. Existeix una significativa correspondència entre les malalties tractades per un i l'altre autor, per més que el canceller hi descriga un major nombre de malalties i hi dedique un extens capítol a cadascuna:

\begin{tabular}{|c|c|}
\hline Ayala, Libro de la caza de las aves & Rocabertí, Llibre de cetreria \\
\hline \multicolumn{2}{|c|}{ Malalties } \\
\hline agua, agua vidriada & aigua, aigua congelada \\
\hline filandras o filomeras & filandres \\
\hline- & pantaix \\
\hline De la caída o debatedura del falcón & cascament \\
\hline pierna, ala quebrada & trencadura de os \\
\hline güérmezes & càncer \\
\hline clavos & poretes \\
\hline
\end{tabular}

Tanmateix, tot i la coincidència en les malalties tractades, els remeis proposats són significativament diferents, cosa que suggereix que Rocabertí podria haver preferit altres fonts o la seua pròpia experiència a l'hora d'oferir les cures apropiades. També cal destacar el fet que el vescomte es refereix a una malaltia, el pantaix, que està absent en l'obra d'Ayala. Referent a això cal assenyalar que el pantaix és una malaltia que apareix habitualment en les obres catalanes de falconeria, fet que evidencia que era una de les malalties que sovint reconeixien i atenien els caçadors de la Corona d'Aragó. Després de la secció dedicada a les malalties, ambdues obres ofereixen indicacions sobre la muda de les aus:

\begin{tabular}{|l|l|}
\hline $\begin{array}{c}\text { Ayala, Libro de la caza de las aves } \\
\text { (p. 407) }\end{array}$ & $\begin{array}{c}\text { Rocabertí, Llibre de cetreria } \\
\text { (f. 10v) }\end{array}$ \\
\hline & Muda \\
\hline Cómo deves fazer la muda a tu falcón & Si vols fer mudar falcons o sparvers o stors [...] \\
\hline
\end{tabular}

I ací, de nou, la informació proporcionada pel canceller és molt més gran, amb una dedicació de tres capítols a tot allò relacionat amb la renovació del plomatge dels ocells de caça, en comparació amb les breus instruccions proposades pel vescomte. L'obra del canceller prossegueix amb uns breus capítols dedicats a altres aus emprades per a la caça -astors, esparvers, esmirles i falcons mostatxutsi algun capítol amb informació miscel-lània que no té correspondència en l'obra de Rocabertí. 


\section{Ricardo M. Olmos de León \& Carmel Ferragud. El Llibre de cetreria del vescomte}

de Rocabertí

Conclou el nostre tractat amb quatre receptes per al pantaix, que trenca així l'estructura ordenada que caracteritza l'obra. És raonable pensar que aquestes quatre receptes siguen addicions incorporades posteriorment a algun dels manuscrits que conservava l'obra del vescomte i que, molt possiblement, foren copiades per una altra persona, algun caçador que desitjava conservar unes receptes que va poder obtenir d'algun altre receptari o per via oral. En realitat, l'addició d'aquests breus textos als manuscrits de falconeria va ser un fenomen molt comú i un gran nombre dels que s'han conservat contenen aquestes valuoses incorporacions (Fradejas 1998: 46; Fradejas / Dietrick 2017).

Ara bé, si aquest estret paral-lelisme en l'estructura de les obres d'Ayala i Rocabertí suggereix que aquest pogué basar-se en l'obra d'aquell i adoptar-la com a model, el contingut, com hem comentat, especialment el terapèutic, difereix significativament i no podem afirmar que la font del vescomte, a l'hora de proposar remeis per a les diverses malalties, fora l'obra del canceller. $\mathrm{Cal}$, doncs, plantejar si el nostre autor va recórrer a la seua pròpia experiència o si, per contra, va obtenir la informació d'altres tractats de falconeria.

No es pot afirmar que les receptes proposades per Rocabertí siguen completament originals i que no es troben en altres textos de l'art. De fet, un estudi detingut de les malalties i remeis proposats permet constatar que pràcticament tota la informació terapèutica es troba en els diversos tractats que es van compondre en l'àmbit de la Corona d'Aragó. No obstant això, com veurem, les relacions que es poden establir amb altres obres no són tan estretes com per a suggerir que va existir una relació directa entre l'obra del vescomte i aquelles que comparteixen alguns dels seus continguts. Una de les dificultats per determinar relacions clares rau en la brevetat i senzillesa de les receptes que proposa Rocabertí, sovint limitades a una única substància, fet que fa difícil determinar la dependència d'altres obres, ja que aquestes substàncies es poden trobar, en la major part dels casos, en les receptes proposades en altres tractats; la simple coincidència en una substància és un argument feble per a afirmar que una haja estat font de l'altra o que hagen tingut una font comuna. A més d'aquestes consideracions, la constatació d'una relació significativa en alguna recepta porta a la qüestió de la determinació de quina de les obres va ser la font de l'altra -O si es va tractar d'una font compartida-, una cosa no sempre senzilla, entre altres raons per la imprecisió en la datació d'alguns dels tractats.

Mostrem a continuació les relacions localitzades entre els continguts de l'obra de Rocabertí i diverses de les obres italianes i catalanes que van circular per la Corona d'Aragó, on s'observarà la major o menor proximitat d'aquests continguts. ${ }^{6}$

Per a la malaltia de l'aigua congelada, Rocabertí, a més d'una de les substàncies més habituals en les obres de falconeria, com és la senfragia-també coneguda per les seues formes derivades de

6 Per a aquest estudi hem considerat les següents edicions i manuscrits: Tractat per l'art de la casa (Mas / Garcia 2013), Libre de casa (Garcia 2013), Pratica de citreria de Maties Mercader (Melchor 2017), Ricettario di Missere Panuntio (Lupis / Panunzio 1992: 91-137), Tractat de medicina per tots els ocells de caça (Mas 2021), Llibre dels ocells de caşa (Garcia 2021), Receptari de Perellós de Pacs (Bover / Rosselló 2003: 173-177), De las suertes de los falcones, Biblioteca Nacional de España (BNE) (Madrid), ms. 4260.

SCRIPTA, Revista internacional de literatura i cultura medieval i moderna, núm. 17 / juny 2021 / pp. 237-279 ISSN: 2340-4841· doi:10.7203/SCRIPTA.17.209914 
l'àrab, caparrós o fabarràs-, en proposa una de poc comuna, el suc de regalíssia, i que només hem localitzat en un parell d'obres. En aquest cas, la relació més estreta la trobem amb l'obra que acompanya la del vescomte en el manuscrit, el Tractat per l'art de la caça:

\begin{tabular}{|c|c|c|c|}
\hline \multicolumn{4}{|c|}{ Aigua congelada } \\
\hline $\begin{array}{l}\text { Llibre de cetreria } \\
\text { (f. } 6 \mathrm{r} \text { ) }\end{array}$ & $\begin{array}{l}\text { Tractat per l'art de la } \\
\quad \text { caça (p. 113-114) }\end{array}$ & $\begin{array}{l}\text { Pratica de citreria } \\
\text { (p. 137) }\end{array}$ & $\begin{array}{l}\text { Llibre de caça } \\
\quad \text { (p. 269) }\end{array}$ \\
\hline $\begin{array}{l}\text { Vós areu suc de } \\
\text { regualícia, et dar-li-eu en } \\
\text { dos o tres jorns, tan com } \\
\text { miga avelana cada volta, e } \\
\text { açò ans qui.l pescau duas } \\
\text { o tres hores, et açò la i } \\
\text { molificarà. }\end{array}$ & $\begin{array}{l}\text { E per a curar aquesta } \\
\text { malaltia fet axí; prendas } \\
\text { suc de rugolícia e dar-li- } \\
\text { u-as uns tres o quatre jorns } \\
\text { en dejú tant com miga } \\
\text { avelana }\end{array}$ & $\begin{array}{l}\text {... o, meglio che tucto, } \\
\text { regulitia preparata. }\end{array}$ & \\
\hline $\begin{array}{l}\text { E aprés aureu seufràgia, } \\
\text { e cascar-la-eu un poc, e } \\
\text { aprés metereu-la en un } \\
\text { drapet de li et metereu-la } \\
\text { a remolyar in una poca } \\
\text { d'aigua tèbea; et de açò } \\
\text { metteu-li en les ventanes. }\end{array}$ & $\begin{array}{l}\text { Se deu donar en aquesta } \\
\text { manera quant l'an mester: } \\
\text { pendreu quatre o sinc grans } \\
\text { seufragie e parar-los-heu } \\
\text { e motar-los-heu e metreu- } \\
\text { los en un draped de li e } \\
\text { pendreu let de donna o } \\
\text { de cabres, tanta quantitat } \\
\text { quant ne cabrà en una } \\
\text { coleretta, e si asò no porreu } \\
\text { haver, agau altra tanta } \\
\text { aigua tèbea, e sia fet axí: } \\
\text { preneu lo dit drap ab los } \\
\text { dits grans e meteu-los en la } \\
\text { dita let o en l'aygua tèbea, } \\
\text { e meteu-li-u en les nafres }{ }^{7} \\
\text { tres jorns amb una palma. }\end{array}$ & & $\begin{array}{l}\text { E, per a fer-li lançar } \\
\text { l'aygua del cap, farets } \\
\text { axí, dats-li fabaraz en } \\
\text { esta manera: per lo } \\
\text { matí en dejú, ans que } \\
\text { li donets res a menjar, } \\
\text { a ora de mises majors, } \\
\text { preneu quatre o cinch } \\
\text { grans de fabaraz e } \\
\text { parau-los de la crosta, e } \\
\text { machucau-los, e meteu- } \\
\text { los en un drap de lli } \\
\text { oldà que sia línpio [...] } \\
\text { E depuix preneu lo } \\
\text { ocell destrament e ab } \\
\text { un bastonet o un cap de } \\
\text { agulla posau-li'n dins } \\
\text { en cada ventana del } \\
\text { nas tres gotes. }\end{array}$ \\
\hline
\end{tabular}

Per a la malaltia de l'aigua, la relació més estreta es troba en una recepta de la Pratica de citreria de Maties Mercader, encara que també es pot vincular amb alguna recepta afegida al llibre De las suertes de los falcones i una altra en el Tractat de medicina per tots els ocells de caça:

7 Es tracta d'una errada evident per nefas, terme català equivalent al castellanisme 'ventanes'. 


\begin{tabular}{|c|c|c|c|}
\hline \multicolumn{4}{|c|}{ Aigua } \\
\hline $\begin{array}{l}\text { Llibre de cetreria } \\
\quad \text { (f. } 6 \mathrm{r}-\mathrm{v})\end{array}$ & $\begin{array}{c}\text { Pratica de citreria } \\
\text { (p. 137) }\end{array}$ & $\begin{array}{c}\text { Recepta afegida al llibre } \\
\text { De las suertes de los } \\
\text { falcones (f. 108v) }\end{array}$ & $\begin{array}{l}\text { Recepta afegida al } \\
\text { Tractat de medicina per } \\
\text { tots els ocells de caça (p. } \\
\text { 375) }\end{array}$ \\
\hline $\begin{array}{l}\text { Pendreu una poca de } \\
\text { mostala e picar-la-eu e } \\
\text { mesclar-la-eu ab una poca } \\
\text { de mel e fer-n'eu rodolí, } \\
\text { axí com un gra de avelana, } \\
\text { e prendereu-ne la mitat, } \\
\text { et fregar-li-eu lo paladar, e } \\
\text { asò la i farà lansar. E axí } \\
\text { meteix, si voleu que non } \\
\text { sia tan fort la medisina, } \\
\text { areu una poca de oruga } \\
\text { e fer-n'eu lo rodolí desús } \\
\text { dit, e axí meteix la i farà } \\
\text { lansar. E axí meteix, i } \\
\text { és bona una píndola de } \\
\text { agari si té gens de la dita } \\
\text { aigua en lo ventrell. } \\
\text { Axí meteix, areu rail de } \\
\text { silidònia e fer-la-eu neta e } \\
\text { raureu-la e meteu-la dos o } \\
\text { tres horas en un poc d'oli, } \\
\text { fet trosets com una mela } \\
\text { pelada, e donau-la-i; e, si } \\
\text { té aigua en lo ventrell, la i } \\
\text { farà lansar. }\end{array}$ & $\begin{array}{l}\text { Ponnocea donareb sei } \\
\text { o septe petzi piccoli } \\
\text { di celidonia mundati } \\
\text { et passati per oglio la } \\
\text { matina in deiuno o una } \\
\text { pillola de arruca grossa } \\
\text { como una nucella, o } \\
\text { due o tre, secondo sarà } \\
\text { il falcone, ad arbitrio et } \\
\text { discretione del cacziatore. } \\
\text { Queste tali pillole } \\
\text { annectano lo stomacho } \\
\text { maraviglosamente }\end{array}$ & $\begin{array}{l}\text { Toma mostacia et oruga, } \\
\text { de cada uno la mitad, et } \\
\text { con un poco de agrico sea } \\
\text { fecho huna píndora con } \\
\text { huna poca miel rosada } \\
\text { colada sea fecha una } \\
\text { píndola que sea de grueso } \\
\text { como el cabo del dedo } \\
\text { pechenyo. } \\
\text { Toma un grano de } \\
\text { azévar cricrotrí et pícalo } \\
\text { bien et avrás un poco } \\
\text { de agaricón molido et } \\
\text { dada la cuarta parte et } \\
\text { con miel rosada colada } \\
\text { sea fecha píndora como } \\
\text { un garvanço o poco más, } \\
\text { et sea dado de manyana } \\
\text { como se costunbra. }\end{array}$ & $\begin{array}{l}\text { Ítem, salònia, altretant. } \\
\text { Ítem, cendra de sarments, } \\
\text { altretant. Ítem, pebre } \\
\text { he oruga, de quada hu } \\
\text { altretant. }\end{array}$ \\
\hline
\end{tabular}

Rocabertí proposa cinc substàncies com a remeis diferents per als filandres. Tres (safrà, all, donzell) són relativament freqüents en les obres de falconeria, i formen part de receptes per a tractar la mencionada malaltia, i així les trobem, per exemple, en el Llibre de caça. Les altres dues, «aigua en què agen bolit faves negres» $\mathrm{i}$ «rave galesch», no hem pogut localizar-les entre els remeis proposats en altres tractats per a aquesta malaltia.

El pantaix és una malaltia de la qual se solen ocupar els tractats de falconeria compostos a la Corona d'Aragó i per a la qual es proposen un bon nombre de remeis. La nostra obra conté una recepta en la secció terapèutica i quatre receptes més al final, el que sembla ser una addició posterior. La primera recepta té la relació més pròxima en el Tractat per l'art de la caça, encara que una de las dues substàncies (femta de homo) es troba també en el Llibre de caça i en el Tractat de medicina per tots els ocells de caça com a remei per a la mateixa malaltia: 


\begin{tabular}{|l|l|}
\hline \multicolumn{2}{|c|}{ Pantaix } \\
\hline \multicolumn{1}{|c|}{$\begin{array}{c}\text { Llibre de cetreria } \\
\text { (f. 7v) }\end{array}$} & \multicolumn{1}{c|}{$\begin{array}{c}\text { Tractat per l'art de la caça } \\
\text { (p. 117) }\end{array}$} \\
\hline \multicolumn{1}{|c|}{$\begin{array}{l}\text { Et per açò pren femta de homo seca e polveriza-la } \\
\text { e passa-la per sedàs de serdes de porc, }{ }^{8} \text { e talia-les } \\
\text { menudes e mescla-u ab la dicta pólvera, e dona-le-y } \\
\text { ab lo past calent, e totes jorns fins a tant qui conegas } \\
\text { que-l dit falcó miliore. Et feu-lo star a la serena fins a } \\
\text { tant conegau sia guarit. }\end{array}$} & $\begin{array}{l}\text { Per falquó que tingua pantaix prim fempta de home } \\
\text { secca o polvoriza-la e ages sedes de porc e capola-les } \\
\text { menudes e mescla-les ab la ditta pólvora, e dau-li- } \mathrm{u}\end{array}$ \\
.VIII. o .VIIII. jorns.
\end{tabular}

Pel que fa a les quatre receptes del final, cadascuna suggereix unes relacions més o menys estretes amb diverses obres. Per a la primera d'elles, la relació amb el Llibre de caça és molt clara, encara que algunes prescripcions del remei de Rocabertí també es troben en la Pratica de citreria:

\begin{tabular}{|l|l|l|}
\hline \multicolumn{1}{|c|}{$\begin{array}{c}\text { Llibre de cetreria } \\
\text { (f. 11v) }\end{array}$} & \multicolumn{1}{|c|}{$\begin{array}{c}\text { Llibre de caça } \\
\text { (p. 312) }\end{array}$} & \multicolumn{1}{|c|}{$\begin{array}{c}\text { Pratica de citreria } \\
\text { (p. 159) }\end{array}$} \\
\hline $\begin{array}{l}\text { Per lo falcó que té pantaix, } \\
\text { prendràs dels cols blanches e levar } \\
\text { les fules, e dels tronchos piqua'ls e } \\
\text { fes-ne suc, e prendràs coral blanch } \\
\text { e fera'ns pólvora ben molta e ben } \\
\text { cernuda, e mesclar-l'as ab lo dit suc } \\
\text { e dar-li-u-as a mengar ab la carn } \\
\text { qui li daràs de quatre en quatre } \\
\text { dies. Et porta'l totes dies a l'aigua } \\
\text { corrent e, si volrà beure, asò li } \\
\text { farà gran }\end{array}$ & $\begin{array}{l}\text { E, per a guarir-lo, curau-lo axí: } \\
\text { primerament, tots jorns tro sia } \\
\text { ben guarit, lo portau a la aygua } \\
\text { corrent si-n voldrà beure o si·s } \\
\text { vol banyar, e, si-n vol beure, } \\
\text { dexau-lo fartar; e, axí mateix, tro } \\
\text { sia ben guarit, que-l façats dormir } \\
\text { al seré davall algun cubertiz totes } \\
\text { nits [...] preneu de les penques de } \\
\text { les cols blanques e levau-ne les }\end{array}$ & $\begin{array}{l}\text { Al dicto male def pantascio, } \\
\text { quello che io ce so è questo: } \\
\text { prenderite passule et fico bianche } \\
\text { secche et faretele bullire in } \\
\text { acqua; da poi le cavarite da là } \\
\text { et dentra una scutella, con le } \\
\text { manu le disfarite tucte. Da poi le } \\
\text { tornerite ad fare buglire in quella } \\
\text { medesima pignatella, cularitelo } \\
\text { poi con un disfarite tucte. Da poi } \\
\text { le tornerite }\end{array}$ \\
\hline
\end{tabular}

8 En aquest passatge hi ha una errada on es confon l'instrument, sedàs, que sovint es diu que ha de ser de seda, amb les cerres del porc. 


\begin{tabular}{|l|l|l|}
\hline $\begin{array}{l}\text { ben. Encara lo faràs dormir a la } \\
\text { serena, e asò lo guarrà. }\end{array}$ & $\begin{array}{l}\text { fulles, que romanguen solament } \\
\text { los tronchos, e picau-los e traheu- } \\
\text { ne lo such e, depuix, preneu } \\
\text { coral blanch e moleu-lo bé, e } \\
\text { fets-ne pólvora ben molguda e } \\
\text { cernuda ab cedàs de seda ... }\end{array}$ & $\begin{array}{l}\text { ad fare buglire in quella } \\
\text { medesima pignatella, cularitelo } \\
\text { poi con un panno sottile et in } \\
\text { quella colatura mescolarite della } \\
\text { polvere del corallo bianco ben } \\
\text { polverizzato et in dicta aqua et } \\
\text { polvere bagnarite lo pasto. }\end{array}$ \\
& $\begin{array}{l}\text { Lo falcone o sparviero farite che } \\
\text { dorma alla serena o in loco dove } \\
\text { li tocchi mezza serena secundo } \\
\text { el tempo. Monstrareteli l'acqua } \\
\text { spesso finché ne voglia per } \\
\text { provare se vorrà bevere. }\end{array}$ \\
\hline
\end{tabular}

La segona de les receptes es pot relacionar més dèbilment amb una d'afegida al Tractat de medicina per tots els ocells de caça i aquesta, però, ofereix una relació molt clara amb una altra recepta del Tractat per l'art de la caça però proposada, sorprenentment, per a curar una altra malaltia, els porrets. Aquesta correspondència suggereix que hi va haver alguna errada en el procés de transmissió de coneixements, una cosa que es constata amb freqüència i que degué constituir una situació habitual:

\begin{tabular}{|l|l|l|}
\hline \multicolumn{1}{|c|}{$\begin{array}{c}\text { Llibre de cetreria } \\
\text { (f. 11v) }\end{array}$} & $\begin{array}{c}\text { Recepta afegida al Tractat de } \\
\text { medicina per tots els ocells de caça } \\
\text { (p. 375) }\end{array}$ & $\begin{array}{c}\text { Tractat per l'art de la caça } \\
\text { (p. 117) }\end{array}$ \\
\hline $\begin{array}{l}\text { dau-li aygua de indívia a beure, e } \\
\text { guarerà, qui provat és. }\end{array}$ & $\begin{array}{l}\text { Aver riubàrber e raureu hun poc, } \\
\text { en cantitat d'una lentila, en aygua } \\
\text { d'endívia, e fer-le star tota la nit a } \\
\text { l'ayre. }\end{array}$ & $\begin{array}{l}\text { [A mal de porretes] usau a lo } \\
\text { falc l'aigua de la ondívia ab bo } \\
\text { riubarbre e sia mesa a la serena } \\
\text { e dau-li-u ab la carn, que asò.ls té } \\
\text { molt sans del fetge. }\end{array}$ \\
\hline
\end{tabular}

La tercera de les receptes per a aquesta malaltia també es pot relacionar amb altres dues obres, la de Mercader i el Llibre de caça:

\begin{tabular}{|l|l|l|}
\hline \multicolumn{1}{|c|}{$\begin{array}{c}\text { Llibre de cetreria } \\
\text { (f. 12r) }\end{array}$} & \multicolumn{1}{|c|}{$\begin{array}{c}\text { Llibre de caça } \\
\text { (p. 312) }\end{array}$} & \multicolumn{1}{c|}{$\begin{array}{c}\text { Pratica de citreria } \\
\text { (p. 160) }\end{array}$} \\
\hline $\begin{array}{l}\text { Altra quura per la ditta malaltia: } \\
\text { prendràs fempta de cabrit petit, } \\
\text { e sequar-l'as e fer-n'as pòlvora ben } \\
\text { cernuda, e dar-li-u-as totes dies a } \\
\text { mengar ab la carn, una poca fins a } \\
\text { tant sia guarit. }\end{array}$ & $\begin{array}{l}\text { preneu femta de fadrí petit, e } \\
\text { secau-la al sol que-s puxa molre } \\
\text { e, si no, secau-la en una teula que } \\
\text { sia límpia al forn, de manera que.s } \\
\text { puxa molrre per a dar-li'n tantost }\end{array}$ & $\begin{array}{l}\text { Sterco di capretto factone polvere } \\
\text { al sole o al foco et dateline dentro } \\
\text { lo pasto che è utilissimo. }\end{array}$ \\
\hline
\end{tabular}


La relació entre la recepta de Rocabertí i la de Mercader és evident, ja que en ambdues es recorre a una mateixa substància, la «fempta de cabrit petit», que, d'altra banda, no apareix com a remei en altres tractats. Tanmateix, la relació amb el Llibre de caça mereix una reflexió. En aquest sembla haver-se substituït la «femta de cabrit petit» per la «femta de fadrí petit», fet que es podria deure a una errada comesa pel compilador anònim del Libre de caça o que ja existia en la seua font. No obstant això, tenint en compte l'actitud de l'esmentat compilador, que reelaborava i reorganitzava els continguts de les seues fonts, és molt possible que la substitució de la substància fora una decisió conscient, i que preferira recórrer a una altra més freqüentment emprada per a l'elaboració de medicines per a les aus i proposada en altres llocs de l'obra.

L'última de les receptes per al pantaix, que recorre a les granotes com a medicament, també ofereix elements per a la reflexió, ja que es tracta d'una substància habitualment prescrita, des de la tradició llatina, per a la muda de les aus i no per a la malaltia que ara ens ocupa. Aquest fet fa que la coincidència en aquest remei per a curar el pantaix en una altra obra cobre rellevància $i$ suggeresca una relació entre les dues:

\begin{tabular}{|l|l|l|}
\hline \multicolumn{1}{|c|}{$\begin{array}{c}\text { Llibre de cetreria } \\
\text { (f. 12r) }\end{array}$} & $\begin{array}{c}\text { Tractat per l'art de la caça } \\
\text { (p. 117) }\end{array}$ & \multicolumn{1}{c|}{$\begin{array}{c}\text { Llibre dels ocells de caça } \\
\text { (p. 300) }\end{array}$} \\
\hline $\begin{array}{l}\text { Per falqó o estor qui té pantaix, } \\
\text { pren granotas e fer-les netes, e } \\
\begin{array}{l}\text { aprés sequa-les e fes-ne pólvora, e } \\
\text { dona al falcó o astor a mengar vil o } \\
\text { nou dies, e guarrà sens duptes. }\end{array}\end{array}$ & $\begin{array}{l}\text { Axí meteix, res bo del cuirons e de } \\
\text { les granotes ben seques e dau-li a } \\
\text { mengar } \cdot V \cdot \text { o } \cdot V I \text {. jorns e guarrà. }\end{array}$ & $\begin{array}{l}\text { [muda] crema una granota, e de la } \\
\text { pólvora de haquella tu li dóna a } \\
\text { menyar. }\end{array}$ \\
\hline
\end{tabular}

La substància proposada per Rocabertí per a guarir el «falcó cascat» és la pólvora de ben Mesué i sembla que es tractava d'un remei per als traumatismes dels ocells molt conegut i popular entre els caçadors de la Corona d'Aragó -igual que podia ser la momia en Castella-, ja que apareix en nombroses obres compostes en italià $i$ en català, entre les quals, un dels tractats d'Enyego d'Àvalos, qui proposa «el ben mesue per roctura» (Lupis 1975: 76). La relació més estreta de la recepta de Rocabertí una altra vegada sembla estar en una recepta afegida al Tractat de medicina per tots els ocells de caça: 


\begin{tabular}{|c|c|c|c|}
\hline \multicolumn{4}{|c|}{ Cascament } \\
\hline $\begin{array}{l}\text { Llibre de cetreria } \\
\text { (f. } 8 \mathrm{r} \text { ) }\end{array}$ & $\begin{array}{l}\text { Recepta afegida al } \\
\text { Tractat de medicina per } \\
\text { tots els ocells de caça (p. } \\
\text { 375) }\end{array}$ & $\begin{array}{c}\text { Tractat per l'art de la } \\
\text { caça } \\
\text { (p. 117) }\end{array}$ & $\begin{array}{l}\text { Pratica de citreria } \\
\text { (p. 157) }\end{array}$ \\
\hline $\begin{array}{l}\text { Quant lo falquó és } \\
\text { casquat, dar-li-eu pólvera } \\
\text { de ben Mesué et dar-li-eu } \\
\text { ab lo past calent; i, per } \\
\text { quascat que sia, lo guarerà. }\end{array}$ & $\begin{array}{l}\text { Per oçel cascat auràs } \\
\text { pólvora de bemesué e } \\
\text { d'aquella li daràs ab la } \\
\text { carn tres voltes la semana } \\
\text { o més. Res més, a ton } \\
\text { arbitre. }\end{array}$ & $\begin{array}{l}\text { És molt bo lo moritort } \\
\text { quant haveu dupte que } \\
\text { lo falquó sia casquat però } \\
\text { molt milior és la pólvora } \\
\text { per a casquament que.s } \\
\text { diu de ben mesué. }\end{array}$ & $\begin{array}{l}\text { Soleno gettare sangue } \\
\text { per lo fundamento o per } \\
\text { cascamento, o per colpo } \\
\text { receputo, o per cascata o } \\
\text { vena ropta. Se per colpo } \\
\text { o cascamento li donerite } \\
\text { una presa di ben Mesue } \\
\text { et nasturzo come di sopra } \\
\text { è dicto }\end{array}$ \\
\hline
\end{tabular}

Les correspondències mostrades assenyalen, addicionalment, una relació més estreta entre l'obra de Mercader i el Tractatper l'art de la caça, ja que en ambdues es combina la pólvora de ben Mesué amb el morritort (it. nasturzo).

La recepta que prescriu Rocabertí per a la «trencadura d'os» resulta molt interessant ja que ofereix un remei, l'herba margarita, molt poc habitual i que solament hem pogut localitzar en altres dues obres, la de Mercader i el Llibre de caça. Això podria suggerir que es tractava d'un remei conegut o difós específicament al regne de València, que és on plausiblement podem situar les obres esmentades i els seus autors. Aquesta coincidència permet, a més, valorar l'estratègia compositiva de l'autor del Llibre de caça, que no es va limitar a copiar receptes senzilles, sinó que les va prendre com a punt de partida per a desenvolupar tot un tractament en el qual explicava cada pas amb el mínim detall, des de la preparació dels medicaments fins l'adequada administració:

\begin{tabular}{|l|l|l|}
\hline \multicolumn{2}{|c|}{ Trencadura d'os } \\
\hline \multicolumn{1}{|c|}{$\begin{array}{c}\text { Llibre de cetreria } \\
\text { (f. 8r) }\end{array}$} & \multicolumn{1}{|c|}{$\begin{array}{c}\text { Llibre de caça } \\
\text { (p. 325) }\end{array}$} & $\begin{array}{c}\text { Pratica de citreria } \\
\text { (p. 157) }\end{array}$ \\
\hline $\begin{array}{l}\text { Vós areu de la herba que dien } \\
\text { margarita, qui fa lo flor blanca; } \\
\text { e piquar-la-eu et dar-la-eu lo suc a } \\
\text { beure. Et de la herba piquada posar- } \\
\text { li-heu en la trenquadura, e guarerà } \\
\text { en cort. }\end{array}$ & $\begin{array}{l}\text { Hi a un esperhiment per a guarir } \\
\text { en breu lo falcó ho lo ocell que } \\
\text { tendrà la cama ho la cuxa ho la ala } \\
\text { ho altre hos del cos trencat, però } \\
\text { que no li aja ronput lo cuyro ni li } \\
\text { hixca sanch ni hos, e és aquest lo } \\
\text { dit esperiment: }\end{array}$ & $\begin{array}{l}\text { Mumia quanto una nucella. } \\
\text { Pecegreca quanto un terzo di } \\
\text { nucella. Herba margarita la quarta } \\
\text { parte. }\end{array}$ \\
\hline
\end{tabular}




\begin{tabular}{|l|l|l|}
\hline & preneu de una erba que a nom \\
margarita e picau-la e traheu-ne & \\
such; e, quant tendrets lo such tret, & \\
dresau la cuxa ho la cama ho la ala & ho ço que tendrà trencat lo ocell, e & \\
lligau-li ses canyetes ab ses benes no & molt estretes, axí com dit és desús \\
en lo altre capítol com se deuen & lligar les trencadures si són en lloch \\
que.s puxen lligar. & \\
\hline
\end{tabular}

Tanmateix, una anàlisi més detallada ens condueix a plantejar la conjectura que l'berba margarita fora un dels mots amb què, en determinats llocs, es coneixia la planta que Ayala denominava yerva menudilla, denominada també suelda menor. La raó d'aquesta sospita és que Mercader la inclou en una recepta per a elaborar un medicament (consolda) que correspon quasi perfectament amb la recepta que el canceller Pero López de Ayala ofereix per a la seua suelda:

\begin{tabular}{|l|l|}
\hline \multicolumn{1}{|c|}{$\begin{array}{c}\text { Pratica de citreria } \\
\text { (p. 157) }\end{array}$} & \multicolumn{1}{|c|}{$\begin{array}{c}\text { Libro de la caza de las aves } \\
\text { (pp. 340-341) }\end{array}$} \\
\hline $\begin{array}{l}\text { li darite la consolda deli cacziaturi, la quale è questa: } \\
\text { Mumia quanto una nucella. } \\
\text { Pecegreca quanto un terzo di nucella. } \\
\text { Herba margarita la quarta parte. } \\
\begin{array}{l}\text { Psylio minuto la quarta parte } \\
\text { Sementa de nasturzo la octava parte. }\end{array}\end{array}$ & $\begin{array}{l}\text { E la suelda se faze d'esta guisa [...]: } \\
\text { toma la mumia que tienen los boticarios e espeçieros } \\
\text { e la pez e azargatona e la simiente de la yerva } \\
\text { menudilla que llaman suelda menor e simiente de } \\
\text { mastuerço e suelda rata, e de la mumia sea la mayor } \\
\text { parte e de suelda menudilla la quarta parte, e de pez } \\
\text { dos partes, entiéndese el teçio menos que la mumia, } \\
\text { e de azargatona la quarta parte, e de la simiente del } \\
\text { mastuerço la ochava parte, e de suelda rata ochava } \\
\text { parte, e todo esto es al respecto de la mumia }\end{array}$ \\
\hline
\end{tabular}

L'estreta relació entre les receptes és evident, tant pel que fa als ingredients com per les seues proporcions i, perquè l'azargatona es pot fer correspondre amb el psylio, l'berba margarita hauria d'estar en el lloc de la yerva menudilla. En qualsevol cas, sembla que en aquesta ocasió l'autor del Llibre de caşa desconeixia alguna d'aquestes denominacions, ja que en la seua compilació esmenta, en diferents receptes, tant l'«erba que à nom margarita» com l'«erba menudina, en altra manera apellada pinpinella», sense que semble identificar-les amb una mateixa planta.

També sembla que les substàncies proposades pel vescomte per a la cura del càncer a la boca de les aus, la tinta i el suc de llimona, van gaudir d'una gran popularitat a la Corona d'Aragó, ja que les trobem prescrites per a curar aquesta malaltia en nombroses obres i receptaris, entre aquests, l'anomenat Ricettario di Missere Panuntio i el Receptari de Perellós de Pacs. 


\begin{tabular}{|c|c|c|}
\hline \multicolumn{3}{|c|}{ Càncer } \\
\hline $\begin{array}{l}\text { Llibre de cetreria } \\
\text { (f. 8r-v) }\end{array}$ & $\begin{array}{l}\text { Pratica de citreria } \\
\text { (p. 146) }\end{array}$ & $\begin{array}{l}\text { Llibre de caça } \\
\text { (pp. 287, 293) }\end{array}$ \\
\hline $\begin{array}{l}\text { Les medisines que y són bones són } \\
\text { aquestes: hareu una ploma e, ab la } \\
\text { dicta ploma, denegar-li-eu la boca } \\
\text { del cànser, tan com porreu, et aprés } \\
\text { metereu-li tinta, e asò fareu per dos o } \\
\text { tres jorns, e aprés areu suc de limó, e } \\
\text { asò.l guarrà per encarnat qui sia. }\end{array}$ & $\begin{array}{l}\text { Mundare con una palecta di corno } \\
\text { di cervo o de penna de oqua se è } \\
\text { maturo [...] Toccarite così medesimo } \\
\text { in quello loco con un poco de } \\
\text { bambace ligata et advoltata ad uno } \\
\text { capo de penna con un poco de } \\
\text { succu de limoncello, [...] Et se non } \\
\text { infonderite dicta bambace con un } \\
\text { poco d'incaustroa sive tinta. }\end{array}$ & $\begin{array}{l}\text { e, quant serà llinpiat e netejat, llavau-li } \\
\text { la dita plaga ab un poch de such de } \\
\text { llimó [...] } \\
\text { e ab un poquet de cotó lligat al cap } \\
\text { de(l) un bastonet mullau-lo en la } \\
\text { tinta e untau-li tot lo càncer }\end{array}$ \\
\hline $\begin{array}{l}\text { Tractat per l'art de la caça } \\
\text { (p. 115) }\end{array}$ & $\begin{array}{l}\text { Ricettario di Missere Panuntio } \\
\text { (pp. 124-125) }\end{array}$ & $\begin{array}{l}\text { Receptari de Perellós de Pacs } \\
\text { (p. 177) }\end{array}$ \\
\hline $\begin{array}{l}\text { e si ab axò no guarex, met-li suc de } \\
\text { limó. }\end{array}$ & $\begin{array}{l}\text { Primo: tinta mesclada ab such de } \\
\text { limó, tant de l'ú com de l'altre. [...] } \\
\text { III: fer bien necta la plaga ab una } \\
\text { ploma, e guardar de fer sanch }\end{array}$ & $\begin{array}{l}\text { Quant hun falcó té mal de boca que } \\
\text { casi tira a cranch, fa natagar-li be la } \\
\text { boca sens fer-li sanch y aprés huntar- } \\
\text { la-y de tinta. }\end{array}$ \\
\hline
\end{tabular}

Els porrets (cast. clavos) devia ser una malaltia que sovint patien els ocells a les mans. Molts i diversos remeis es van proposar a l'edat mitjana per a aquesta malaltia, però la prescripció preventiva del vescomte, esvenar, sembla que va ser especialment practicada a la Corona d'Aragó, ja que la trobem en quatre tractats de falconeria del segle XV, mentre que en l'àmbit castellà, anomenada desgobernar, només apareix en una obra de final del XVI. ${ }^{9}$ Es tractava d'una intervenció quirúrgica que seccionava completament la vena que descendia a les mans de les aus i la justificació per a l'esmentada operació, que també s'aplicava a cavalleries o persones, es trobava en la doctrina mèdica del galenisme: tallant els vasos sanguinis que conduïen a les mans de les aus o peus d'equins i persones s'impedia que hi arribaren els humors responsables de la malaltia.

\begin{tabular}{|c|c|c|c|}
\hline \multicolumn{3}{|c|}{ Porretes } \\
\hline $\begin{array}{c}\text { Llibre de cetreria } \\
\text { (f. 9v) }\end{array}$ & \multicolumn{1}{|c|}{$\begin{array}{c}\text { Llibre de caça } \\
\text { (p. 264) }\end{array}$} & $\begin{array}{c}\text { Pratica de citreria } \\
\text { (p. 168) }\end{array}$ & $\begin{array}{l}\text { Tractat per l'art de la caça } \\
\text { (p. 117) }\end{array}$ \\
\hline $\begin{array}{l}\text { E, si'l voleu perfectament } \\
\text { guarir per manera qui } \\
\text { no li tornen, vos li fareu } \\
\text { svenar de ans dues les } \\
\text { mans }\end{array}$ & $\begin{array}{l}\text { svenau-lo destrament, axí } \\
\text { com svenen un rocí o un } \\
\text { hom. }\end{array}$ & $\begin{array}{l}\text { La cura perfecta è svenare } \\
\text { lo falcone da una o de } \\
\text { ambedui le gambe se de } \\
\text { tucti due farà de bisognio. }\end{array}$ & $\begin{array}{l}\text { E, aprés, amb una lanceta } \\
\text { subtilment que sia prima, } \\
\text { svenar-l'eu en les fonts } \\
\text { aprés lo genol }\end{array}$ \\
\hline
\end{tabular}

9 Es tracta del Libro de cetrería de Luis Zapata (Rodríguez 2013: 207-208). Sobre aquesta operació quirúrgica en la cura dels ocells, vegeu Olmos (2019: 167). 
El remei curatiu proposat per Rocabertí per a aquesta malaltia es basa a fondre mantega a l'interior d'una ceba; no l'hem pogut localitzar en cap altra obra, encara que l'operació de fondre mantega a l'interior d'algun altre vegetal sí que la trobem, per exemple, en el llibre De las suertes de los falcones, un tractat escrit durant la primera meitat del segle $\mathrm{XV}$, en el qual es prescriu la mantega fosa en l'interior d'un rave "para el ave que resitará corlas» ${ }^{10}$ o en el Libro de la caza de Juan Manuel, on es recomana per a la malaltia denominada piedra (Fradejas 2001: 187).

Per a finalitzar aquesta anàlisi de relacions entre els continguts del Llibre de cetreria i altres obres sobre la matèria, podem remarcar l'estreta relació entre dues de les prescripcions que el vescomte proposa per a la muda dels ocells i dues receptes que es troben en el Llibre dels ocells de caça: ${ }^{11}$

\begin{tabular}{|c|c|c|}
\hline \multicolumn{3}{|c|}{ Muda } \\
\hline $\begin{array}{l}\text { Llibre de cetreria } \\
\text { (ff. 10v-11r) }\end{array}$ & $\begin{array}{l}\text { Llibre dels ocells de caça (1) } \\
\text { (p. 301) }\end{array}$ & $\begin{array}{l}\text { Llibre dels ocells de caça (2) } \\
\text { (p. 335) }\end{array}$ \\
\hline $\begin{array}{l}\text { Si vols fer mudar falcons o sparvers } \\
\text { o stors, pren caragols e trenqua'ls } \\
\text { un poc les coscles e met-les en } \\
\text { un sachet de li e penga'l al sol, e } \\
\text { met jus un bací; e aquell-aygua qui } \\
\text { caurà dels caragols sia messa en } \\
\text { una copola, e cada volta qui daràs } \\
\text { a mengar al falquó, mula-li de } \\
\text { aquel-aygua lo past de què.l paxerau, } \\
\text { e veureu merevelyàs. } \\
\text { Et, si vols que.l petnage del falquó } \\
\text { sia bianque e bon mudat e gentill, } \\
\text { pren VI o VIII prunes verdes } \\
\text { colides de l'arbre, e meteu-les en } \\
\text { la desús dicta aigua dels caragols. }\end{array}$ & $\begin{array}{l}\text { A mudar aucells faràs aquesta } \\
\text { aygua: que prengues c caragols e } \\
\text { mit-los en un sac de li ho de cànem, } \\
\text { he sien trencades les closques de } \\
\text { aquels. Puys, penya lo sach al sol } \\
\text { e aquella aygua qui degoterà, met- } \\
\text { la hom en una empolla. E, com } \\
\text { hom donerà a menyar a l'aucell, en } \\
\text { aquella aygua sia benyat lo past que } \\
\text { hom li darà a menyar. } \\
\\
\text { Ítem, sia la muda bella e blanca, } \\
\text { axí com a colom, e prin vi ho vii } \\
\text { prunes que hom troba verdes en } \\
\text { l'arbre, e cremar-les-as. E, puys, } \\
\text { mit-les en l'aygua demunt dita ab } \\
\text { lo past. E, com comensarà a gitar } \\
\text { los vans, mulla un poch la carn en } \\
\text { la dita aygua. }\end{array}$ & $\begin{array}{l}\text { Prin ccc caragols, e mit-los en } \\
\text { un sac de li o de cànem, e sien } \\
\text { trencades les closques dels dits } \\
\text { caragols; e, puys, penja lo dit sac al } \\
\text { sol, e aquella aygüe que-n recorrerà } \\
\text { meta-la om en una enpolla, e, com } \\
\text { deràs a menjar a l'aucel, ab aquella } \\
\text { aygua mulla-li lo past que li daràs. } \\
\text { Axí mateix, si vols que isque de } \\
\text { muda bel he net, prin vi o vii } \\
\text { prunes verdes e creme-les, he, } \\
\text { puys, mit-les en la aygua demunt } \\
\text { dita, ab lo past da-li'n, perhò, com } \\
\text { comensarà de lansar les penes, no } \\
\text { metes en la cran de la dita aygua. }\end{array}$ \\
\hline
\end{tabular}

No hem pogut localitzar en altres obres, però, les altres dues substàncies proposades per Rocabertí per afavorir la muda de les aus: «ubagueres» $\mathrm{i}$ «gales».

10 De las suertes de los falcones, BNE, ms. 4260, f. 94r-v.

11 En realitat es tracta de la mateixa recepta, que apareix en dos llocs diferents, ja que el Llibre dels ocells de caça és, en realitat, una juxtaposició de dos tractats que comparteixen algunes receptes. 


\section{Ricardo M. Olmos de León \& Carmel Ferragud. El Llibre de cetreria del vescomte}

de Rocabertí

Com hem vist en les taules anteriors, la major part dels remeis i substàncies medicinals prescrits pel vescomte de Rocabertí es poden localitzar en diversos tractats de falconeria i receptaris escrits a la Corona d'Aragó. No obstant això, la relació més estreta es mostra en cada cas amb receptes d'obres diferents. Tot això fa pensar que cap d'aquests textos va ser emprat directament com a font de continguts pel nostre autor, ni tampoc la seua obra va ser una font directa d'aquells. Resulta molt revelador el fet que, de vegades, les relacions més estretes es troben entre les receptes afegides en els manuscrits que conserven una o l'altra obra. Tot això sembla assenyalar més aviat uns coneixements compartits que circulaven, tant de forma oral com escrita en forma de receptaris, entre caçadors i falconers. En aquest context cobra un gran protagonisme el Ricettario de Missere Panuntio, col-lecció de receptes per a les malalties dels ocells de caça recopilades en la cort napolitana entre 1467 i 1474 pel rei Ferran I, i l'editor ja apuntava a aquesta forma de transmissió de coneixements i proposava la idea de receptaris oberts, en els quals les prescripcions s'anaven incorporant de forma successiva, sovint per persones diferents (Lupis 1979; Lupis / Panuntio 1992: 91-137). Aquest receptari, en el qual es van incloure remeis proposats per diversos caçadors i falconers, constitueix un testimoni valuós del que degué ser una de les formes habituals de transmissió de coneixement relacionat amb les cures de les aus: les receptes compartides de forma oral i escrita entre caçadors. Un altre valuós testimoni d'aquesta forma de transmissió de coneixements el constitueix el Receptari de Perellós de Pacs, un breu compendi de quatre receptes que el noble mallorquí va obtenir en 1541 d'un caçador «qui anava ab las gualeras de don Bernaldino» i qui li va vendre un falcó tunicenc (Bover / Rosselló 2003: 173-177). ${ }^{12}$

Si la semblança estructural entre l'obra d'Ayala i la de Rocabertí suggereix que aquest va poder conéixer l'obra d'aquell, cal preguntar-se per què el vescomte no va incloure en el seu breu tractat els remeis que oferia el canceller. És molt possible que el nostre autor preferira recollir en la seua obra uns remeis amb els quals estava familiaritzat, els que coneixia per haver-los experimentat i que hauria arribat a aprendre per haver-li estat transmesos de forma oral per altres caçadors o en forma de modest receptari, potser albergant una o poques receptes. La diferència entre les substàncies medicinals proposades en el Libro de la caza de las aves i en Llibre de cetrería, així com altres obres de la Corona d'Aragó de mitjans i finals del segle XV, són notables i cal preguntar-se si això es devia a una tradició independent des de temps enrere o bé si es tractava d'una evolució que feia percebre als caçadors dels segles XV i XVI alguns remeis del segle XIV com a antics i inadequats. Hem de tenir en compte que l'obra d'Ayala, escrita al voltant de 1386, va prendre gran part dels continguts mèdics del Livro de falcoaria, escrit en portugués algun temps abans per Pero Menino qui, possiblement, recorreguera al seu torn a una tradició anterior, de manera que entre mitjans $\mathrm{i}$ finals de segle $\mathrm{xV}$, alguns d'aquests remeis potser ja no eren emprats pels caçadors. L'evolució en el temps dels remeis i les cures dels ocells de caça, així com la major o menor adequació entre les prescripcions dels tractats i la pràctica real dels caçadors, són dos aspectes de gran interés que requereixen per al seu estudi l'anàlisi d'un ampli corpus textual i documental que no tindria cabuda en aquesta presentació de l'obra de Rocabertí i que s'està duent a terme per a una publicació posterior. ${ }^{13}$

12 La idea de receptaris oberts no es limita, evidentment, als remeis per a ocells de caça, ja que per a la medicina humana altmedieval es constata aquest fenomen (Ferraces 2019: 46). Sobre la circulació de receptes i la configuració de receptaris per a ús de les persones, que seguia un patró idèntic, és de gran rellevància el treball de Cifuentes (2016).

13 Un estudi sobre la cura dels ocells de caça en l'àmbit castellà es pot trobar en Olmos (2018) i, més detalladament,

SCRIPTA, Revista internacional de literatura i cultura medieval i moderna, núm. 17 / juny 2021 / pp. 237-279 ISSN: 2340-4841· doi:10.7203/SCRIPTA.17.209914 


\section{Ricardo M. Olmos de León \& Carmel Ferragud. El Llibre de cetreria del vescomte}

de Rocabertí

\section{Els ocells de caça de la falconeria medieval en les fonts catalanes}

Com que l'obra que editem és, entre les conservades en català, la que ens ofereix una visió més completa dels ocells de caça, ens ha semblat oportú acompanyar el text amb una anàlisi detallada d'aquestes aus en les fonts catalanes. Un treball semblant ja s'havia inclòs en l'extensa obra de Bover / Rosselló sobre la falconeria a les Balears (2003: 31-56). No obstant això, aquest estudi, a més d'ampliar i completar aquella proposta, en divergeix en alguns punts, el que justifica aquesta nova contribució.

Com a fonts per a l'estudi dels ocells de caça a les fonts catalanes hem descartat els tractats de falconeria estretament dependents de la traducció llatina o àrab, ja que aquests ens ofereixen, amb freqüència, les adaptacions dels termes originals que van poder fer els traductors i rarament els corresponents termes catalans, els emprats pels caçadors de forma habitual. En algunes ocasions hem pres en consideració també algunes obres literàries i, fonamentalment, la documentació d'arxiu.

L'ocell de presa és l'element central de la falconeria, que la caracteritza i diferencia d'altres modalitats venatòries. Durant la baixa edat mitjana els caçadors van recórrer a una gran varietat d'aquestes aus, fet que els permetia capturar preses molt diverses quant a grandària, comportament o hàbitat. Aquesta diversitat va exigir als caçadors medievals desenvolupar un ric vocabulari tècnic per a poder descriure i referir-se amb precisió a cadascuna de les aus emprades. Aquesta rica terminologia, a més, anava associada a una exhaustiva classificació ornitològica segons múltiples criteris, que els permetia reconéixer i especificar moltes de les seues característiques.

En aquest estudi ens referim a les espècies d'ocells i els termes catalans emprats per designar-les, i volem advertir que el terme espècie no s'usa en el sentit de la biologia moderna, sinó per referir-nos al que els caçadors medievals consideraven tipus d'aus diferents, concepte per al qual utilitzaven el terme agre. ${ }^{14}$

El més gran dels ocells emprats per a la caça, i un dels descrits per Rocabertí, era el falcó grifaut o grifalt, ${ }^{15}$ sovint esmentat com grifaut o grifalt..$^{16} \mathrm{El}$ nostre autor, a més de confirmar que es tracta de «lo pus gran et major falcó que sia en lo món», ens aclareix que aquests falcons «venen de terra molt freda». Efectivament, aquests ocells són originaris de les regions més septentrionals d'Euràsia i Amèrica, cosa que va provocar que l'obtenció fora sempre molt difícil per als caçadors de latituds mediterrànies, que només podien aconseguir exemplars pagant enormes sumes als mercaders que els portaven

en Olmos (2015). Actualment treballem en un projecte similar a partir de les fonts de la Corona d'Aragó.

$14 \mathrm{El}$ terme agre tenia altres significats en el llenguatge dels caçadors i el més important, a més de l'esmentat, era el de 'niu' o 'parella d'aus que es reprodueix en un lloc concret'.

$15 \mathrm{Hem}$ prescindit d'assenyalar totes les variants ortogràfiques $\mathrm{i}$ fonètiques que les fonts ofereixen en els termes que es refereixen a les aus; ens limitem a indicar-ne la més freqüent i en forma normalitzada.

16 La documentació d'arxiu, especialment la procedent de la Cancelleria reial i la Tresoreria del rei, conté nombrosissímes referències a aquests ocells: "Quant als falcons de què.s ha parlat vos fem saber que nós n'avem de pelegrins, de griffauts e de sacres e que.ls havem ja fets metre per aquest any en muda, e que si vós ells ésser trets de aquella nos hic embiats vos en trametrem fort volenters d'aquells que volrets. E si entretant hic trametets per los dits cavalls e falcons los vos enviarem mantinent» (Arxiu de la Corona d'Aragó [ACA], Reial cancelleria [C], reg. 1743, f. 186r-v; 15-05-1377).

SCRIPTA, Revista internacional de literatura i cultura medieval i moderna, núm. 17 / juny 2021 / pp. $237-279$ ISSN: 2340-4841 • doi:10.7203/SCRIPTA.17.209914 
-habitualment des de Flandes- o rebent-los com a regal. Malgrat ser considerat, pel seu caràcter i per la dificultat per a l'ensinistrament i maneig, com un «falcó vilà», es tractava d'aus molt preades que només estaven a l'abast dels més poderosos, reis i grans senyors, els quals amb freqüència enviaven exemplars com a present diplomàtic. Així, el rei Pere el Cerimoniós ordena preparar dos grifauts blancs per enviarlos al soldà de Babilònia, amb la intenció de facilitar l'obtenció de les restes de santa Bàrbara: ${ }^{17}$

\footnotetext{
Vescomte, fem vos saber que nós havem ordonat de fer missatgeria al soldà de Babilònia per haver lo cors de sancta Bàrbera, lo qual sobiranament desiam haver. E com segons qu·ens és donat a entendre una de les coses qui induiran lo soldà a donar nos lo dit cors serà que li trametam .II. grifauts blanchs dels quals li haurem la .I. del comte de Flandres a qui n'avem ja tramès.
}

A més de les qualitats per a la caça, que els permetien capturar animals de grans dimensions com les grues o els agrons, aquests falcons també van ser molt preats per la seua bellesa, ja que alguns exemplars eren gairebé completament blancs. El falcó grifalt, a més d'aparéixer amb freqüència en la documentació d'arxiu i en l'obra de Rocabertí, també és esmentat en diverses ocasions en el Llibre de caça, on es fa referència a la seua naturalesa i a les malalties a les quals és més propens, $\mathrm{i}$ s'hi proposen els remeis oportuns (Garcia 2013: 258, 260, 333, 343, 348). Tampoc falten mencions a aquests ocells a la literatura, com en un poema d'Ausiàs March, qui va ser falconer major d'Alfons el Magnànim, on prega al rei que li done un d'aquests falcons (Garcia 1993: 241):

Tot mon delit resta sol en caçar; per què us suplich, dels hòmens vós millor, que d'un grifaut me siau donador, tal que a vos escaiga lo donar.

Una altra de les aus que es descriu en el nostre text i que era emprada pels caçadors de la Corona d’Aragó era el falcó sacre, o simplement sacre. De menor grandària que el grifalt, aquest falcó també va ser molt preat per les seues qualitats per a la caça i la seua obtenció va ser més senzilla i menys costosa que la d'aquell, ja que molts exemplars arribaven de mans de mercaders de l'illa de Creta (anomenada habitualment Càndia), on es capturaven en el pas migratori. ${ }^{18}$ Algunes fonts castellanes del segle XVI afirmen que alguns exemplars també es prenien a la península Ibèrica. ${ }^{19}$ Potser per aquesta raó aquests falcons ja resultaven més accessibles per a caçadors de diversa condició, ja que les fonts ens mostren, per exemple, una d'aquestes aus com a propietat del justícia de València a principis del segle XV. ${ }^{20}$

17 ACA, C, reg. 1089, f. 12r (9-03-1373).

18 «a·n Thomàs Surià, mercader de falcons de la illa de Càndia, ara atrobat en la ciutat de València... per rahó de VIII falcons sacres que lo senyor rey d'ell havia manats comprar a rahó de XV florins per cascu falcó». ARV, Mestre racional, vol. 8763, f. 55r (any 1426).

19 Es tracta del Libro de cetrería de Luis Zapata (Rodríguez 2013: 151-152), on s’afirma que els millor són els de Càndia.

20 ACA, C, reg. 2247, f. 62r (2-02-1404).

SCRIPTA, Revista internacional de literatura i cultura medieval i moderna, núm. 17 / juny 2021 / pp. $237-279$ 


\section{Ricardo M. Olmos de León \& Carmel Ferragud. El Llibre de cetreria del vescomte}

de Rocabertí

Una mica menors que els falcons anteriors, tres agres de falcons molt semblants s'esmentaven entre les aus més estimades pels caçadors per les seues qualitats per a la caça i pel bon caràcter, cosa que els valia el qualificatiu de gentils. El falcópelegrí era un falcó originari del nord d'Europa i que descendia a les regions mediterrànies per a passar l'hivern en latituds més càlides, comportament del qual procedeix el seu nom. ${ }^{21}$ Molts s'adquirien dels mercaders de Flandes, on es capturaven en gran nombre durant el pas migratori, encara que alguns també eren agafats durant la seua hivernada a la península Ibèrica i altres regions meridionals pels paradors. ${ }^{22}$ El falcó munterí o falcó gentil era un ocell molt semblant a l'anterior -«semblan molt en la qualitat als pelegrins», asegura Rocabertí- però sedentari, que nidificava en latituds mediterrànies, cosa per la qual habitualment eren presos dels nius o agres poc abans d'emprendre el vol. Aquestes aus construïen els nius en penya-segats rocosos, cosa que possiblement siga l'origen de la seua denominació de munterins. Gràcies a l'aclariment del vescomte, sabem que ambdós termes, munterí i gentil, que són freqüents en la documentació d'arxiu, es referien al mateix ocell: «Terserament vos diré de altre agre de falquons, als quals apela hom montarins et altres dien gentils». El tercer dels falcons estretament relacionat amb els anteriors és el que Rocabertí denomina tagarot i que sense cap mena de dubte és un castellanisme (cast. tagarote) que designava el falcó anomenat barbaresc en altres fonts catalanes. ${ }^{23}$ De fet, el propi Rocabertí ens informa que «aquests falcons venen de la Barbaria». Que es tractava d'un tipus d'au que els caçadors consideraven estretament relacionada amb l'anterior resulta clar per les ocasions en què apareix denominat com munterí barbaresc. ${ }^{24}$ Malgrat ser de menor grandària que el grifalt i el sacre, aquests tres falcons eren emprats per a capturar aus de grans dimensions, com ens explica el vescomte: «Són falcons molt ardits et per a tota presa grosa, axí com són grues, ostardes, oques, agrons, et matar tota manera de presa grosa, tan gran és lo ardiment qui tenen». Encara que també eren aus apropiades per a la caça de perdius i al seu ensinistrament per a aquesta presa dedica el Llibre de caça un capítol: «Capítol com se deu afaytar falcó monterí o pelegrí a perdiu» (Garcia 2013: 220).

21 Escriu Ayala: «e en Aragón e Cataluña llámanlos pelegrines, por conparaçión de los pelegrinos e romeros que andan por todas las tierras e por todo el mundo, que así son los falcones gentiles o neblís o pelegrinos, que todo el mundo andan e atraviesan con el su bolar partiendo de la tierra donde naçieron» (Delgado 2007: 93).

22 Parador és el mot que hem localitzat en la documentació per a referir-se a la persona que captura falcons per a la caça "per què volem que hajats diligència que.ls paradors aporten aquí tots quants falcons pendran» (Bofarull 1881: 86). En consonància amb aquest terme, un altre document de 1393, pertanyent al Llibre del mostassaf de Mallorca, ens ofereix el verb parar per a l'acció mencionada «Encara mana més lo dit lochtinent de governador, que com alscuns usen mal draquells, qui paren falcons gentils e desfan agres dels dits falcons» (Pons 1949: 231). En una carta amb data del 24 de gener de 1418, els virreis de Sicília escrivien al rei Alfons el Magnànim i li anunciaven «trametem de present dos falcons sors pelegrins d'aquells que.s prenen en la vostra illa de Malta» (ACA, C, Cartes Reials, Alfons IV [V], Sèrie general, 0722).

23 «Vos tenim per escusat de la tramesa dels falcons barbareschs per la rahó que•ns havets allegada» (ACA, C, reg. 1656, f. 8v; 15-02-1380).

24 «Mossèn Francesch, bé creem que us recorda con enguayn en Barcelona vos pregam que.ns féssets vanir de Barbaria quatre falcons muntarins barbareschs mechs dels pus bells que trobar-se poguessen» (ACA, C, reg. 1746, $\mathrm{f}$. 62r; 19-12-1379).

SCRIPTA, Revista internacional de literatura i cultura medieval i moderna, núm. 17 / juny 2021 / pp. 237-279 ISSN: 2340-4841· doi:10.7203/SCRIPTA.17.209914 


\section{Ricardo M. Olmos de León \& Carmel Ferragud. El Llibre de cetreria del vescomte} de Rocabertí

De menors dimensions que els anteriors són els falcons que Rocabertí denomina tunicenc i provençal. En realitat ambdós ocells estaven estretament relacionats, com aclaria Juan Manuel en el seu Libro de la caza, compost en la primera meitat del segle XIV: «Et d'estos ay dos naturas: los unos son de aquen mar, los otros de allen mar; et a los de aquen mar llaman bornís [provençals], et a los de allen mar llaman alfaneques [tunicencs]». Així, els caçadors de llengua catalana denominaven provençals els falcons d'aquesta espècie originaris d'Europa. Pero López d'Ayala, en la seua obra de falconeria, s'atura a explicar on es troba aquest ocell i on es captura, i esmenta explícitament una regió de la Provença com a origen dels millors exemplars (Delgado 2007: 136). Sens dubte, en el fet que en aquesta regió es capturaren molts exemplars i es consideraren de gran valor es troba la justificació del seu nom en català. D'altra banda, els tunicencs, com es desprèn del seu nom, eren els falcons de la varietat nord-africana, que arribaven als regnes de Castella i de la Corona d'Aragó de mans de mercaders. Tant una varietat com l'altra eren emprades habitualment per a la caça de la perdiu i la llebre, com explica Rocabertí, que coincideix amb els autors castellans d'obres de falconeria.

Tot i que Rocabertí no el menciona, convé que ens referim ací a un ocell denominat llaner en la documentació catalana. Caldria pensar que es tracta d'un terme genèric que englobava el provençal i el tunicenc, com explica Pero López de Ayala que es fa en altres llocs: «e al borní [provençal] e al alfaneque [tunicenc] llámanlos laneres». Tanmateix, el fet que aquest mot, fins al present tan sols l'hàgem trobat en la documentació del regne de Mallorca ens condueix a considerar que llaner seria, en les Balears, l'equivalent a provençal en altres territoris de la Corona d'Aragó.

D'aquests falcons cal assenyalar que, a jutjar per la seua presència a les fonts, devien ser molt estimats i emprats a la Corona d'Aragó, possiblement més que a Castella. A més, pel seu menor valor econòmic $\mathrm{i}$ les seues qualitats per a la caça de la perdiu i la llebre, devia ser l'au emprada per caçadors de condició social més modesta, els quals, a més d'esbarjo, obtenien carn per a la cuina. En els tractats de falconeria castellans s'esmenta explícitament que «estos burnjs es buen linaje de alcones por que son poco costosos para los hidalgos que no pueden caçar con otras aves y avn ayudales ala costa dela carne» (Fradejas 2012) i a la Corona d'Aragó els trobem en mans dels donzells, entre altres personatges.

El darrer dels ocells que descriu Rocabertí és el falcó bastard, i el vescomte ens n'explica l'origen: «venen de la alta Alemanya, los quals falcons se mesclan sacres ab proensals, et que la femella sia sacra et lo mascle, proensal». És a dir, segons el nostre autor, es tractaria, com el seu nom indica, d'una au engendrada a partir de dues espècies o agres diferents, el que en llenguatge modern anomenaríem híbrid. Les fonts castellanes coincideixen perfectament en la descripció i denominació, així com en el seu origen (Fradejas 2012):

\footnotetext{
De pocos tienpos aca vienen de alemaña, \& de rrogia que dizen castilla entreçelis, \& llamanlos en aragon bastardos, \& es commo el mulo o la mula que son contra fechos njn es cauallo njn es asno asi el bastardo njn es sacre njn es bornj que el ala cabeça y el rrostro de bornj, \& las manos de bornj, \& las espaldas atreuessadas commo bornj, \& tiene las alas \& la cola, \& el plumaje de los pechos de sacre, \& porque es de dos naturas llama sse bastardo que qujere dezir cosa no bien fecha.
} 


\section{Ricardo M. Olmos de León \& Carmel Ferragud. El Llibre de cetreria del vescomte}

de Rocabertí

Ens podríem preguntar si realment existien aquestes aus, si eren conegudes i emprades pels caçadors, o si, en realitat, es tractava d'uns animals l'existència dels quals es limitava a la tradició llibresca. No tenim dubte que els bastards estaven entre les aus emprades per a la caça ja que, a més de les obres independents que els esmenten, ${ }^{25}$ les hem pogut localitzar en la documentació d'arxiu. Així, el 25 de novembre de 1444, la reina d'Aragó, Maria de Castella, donava instruccions perquè es lliuraren al príncep de Castella «tres falcons, dos bastarts e un sagra», ${ }^{26}$ cosa que constitueix una prova clara del seu ús per a la caça. Tot i que la biologia moderna ha pogut constatar casos d'hibridació entre espècies en la naturalesa, és molt possible que en realitat es tractara d'ocells d'una espècie que tenien alguns trets semblants als de l'altra espècie, circumstància que podria donar-se amb freqüència en els exemplars propis d'altres regions, sense que en realitat es tractara d'un veritable encreuament. No obstant això, aquesta consideració no és rellevant per al nostre estudi, en el qual intentem comprendre la percepció dels caçadors medievals.

Sens dubte, els ocells esmentats pel vescomte eren els falcons més importants i més emprats a la Corona d'Aragó, ja que el seu elenc coincideix gairebé exactament amb el que ens ofereix el Llibre de caça en referir-se a la seua complexió: «e aprés són de los falcons grifants, pus calts de natura e pus delicats que los altres ocells de natura de falcons; e aprés són los pelegrins; e aprés los monterins; e aprés los sacres; e aprés los bastarts; e aprés los proençals; e aprés los tonicenchs» (Garcia 2013: 260).

Ara bé, si atenem els tractats de falconeria escrits en castellà o en altres llengües pròximes durant la baixa edat mitjana, constatem que en aquesta relació falten alguns ocells. Es tractaria, en primer lloc, dels falcons de petita talla, sens dubte molt menys utilitzats per a la caça que els esmentats fins ara. El primer seria l'esmirle, que correspondria al esmerejón dels caçadors castellans. Rocabertí no ens en parla $\mathrm{i}$ en el Llibre de caça només és mencionat en una única ocasió, precisament on l'autor anònim es refereix a la natura i la complexió de les aus: «E per aquests graus matexos podets jutgar los esmirles, car de tantes natures n’i ha com de falcons» (Garcia 2013: 260) i en la que, implícitament, és considerat com un llinatge diferent al dels falcons. Tot i que en alguns tractats catalans de la tradició llatina sí que es mencionen aquests ocells («Del nudriment de l'esmirle», Querol 2018 vol 2: 165), ens interessa especialment la seua aparició en altres fonts que ens acrediten de manera fefaent el seu ús per a la caça per part dels caçadors de la Corona d'Aragó. Així, en una carta del 21 de setembre de 1389, el rei Joan I ordenava: "nos comprets o.ns percaçets dos esmirles e comanats-les a alguna persona qui.lls nós sàpia affeytar a copada» (Bofarull 1882: 101). ${ }^{27}$ L'interés del document no només resideix en el fet que ens confirma el seu

25 Altres obres catalanes, com ara el Llibre de caça, també menciona els bastarts (Garcia 2013: 260).

26 Archivo Histórico de la Nobleza, Frías, C.1, D.39

27 Pel que sembla, el rei Joan I es delectava amb la caça d'aquests ocells, ja que no és l'única ocasió en què ordena que se'n capturen i se n'ensinistren per al seu gaudi personal: «Emperò, volem e us manam que.ns percassets .IIII. smirles e fet-los-nos bé afaytar. E com sien afeytats, si vós entenets a venir a nós, apportat-los-nos, si no enviat-los-nos per persona certa» (ACA, C, reg. 1956, f. 185r). Altres referències als esmirles com a ocells de caça en documents més antics es poden trobar en Querol (2018: 251).

SCRIPTA, Revista internacional de literatura i cultura medieval i moderna, núm. 17 / juny 2021 / pp. 237-279 ISSN: 2340-4841· doi:10.7203/SCRIPTA.17.209914 


\section{Ricardo M. Olmos de León \& Carmel Ferragud. El Llibre de cetreria del vescomte}

de Rocabertí

ús per part dels caçadors i el nom precís amb el qual era conegut, sinó que ens informa d'una de les preses que caçava, la copada, una au petita que habita zones obertes, molt freqüent en els camps de cereal i coneguda hui en dia amb el nom de cogullada. Devia ser un fet conegut que la copada era una presa habitual de l'esmirle fins al punt que aquesta relació arribara a emprar-se en la poesia, com en els versos satírics de Francesc de la Via (segles XIV-XV): «La monja mudà de color/ quant viu la birla,/ si que parech fos asmirla/ detràs copada» (Marco 2015: 133). Per altra banda, la presència en la literatura del nom de l'ocell que ens ocupa confirma que així era efectivament com se'l coneixia.

L'altre ocell de caça que volem comentar és el que en les obres castellanes de falconeria es denomina alcotán, un petit falcó conegut actualment en català com a falcó mostatxut. Malgrat que de la lectura de les esmentades obres es dedueix que era un ocell molt poc emprat i preat per a la caça, resulta una mica desconcertant que en les obres catalanes de falconeria no s'esmente en absolut. Realment els caçadors de la Corona d'Aragó mai van ensinistrar, ni tan sols com a entreteniment o aprenentatge, aquest petit falcó? Sens dubte va ser una au molt poc emprada també en aquests territoris, però després d'una minuciosa exploració de fonts hem pogut localitzar alguns passatges en els quals es fa referència a un animal que hem identificat amb l'alcotán castellà. El terme emprat per designar-lo és, amb diverses variants ortogràfiques, moixeta, i una de les dificultats principals per a poder identificar el nom que en l'edat mitjana es donava a aquest falcó és el fet que aquest terme en l'actualitat designa una gran varietat d'animals en diferents regions: el xoriger, l'aufrany, a la cria femella de la gata, l'òliba, etc.

El primer document en el qual apareix -sota la forma moiseta-, i que ens va fer sospitar que es tractava del falcó mostatxut, és el poema provençal Dels auz̧els cassador, de Daude de Pradas (meitat del segle XIII), tot i que el seu editor identificava el terme amb el xoriguer (Schutz 1945: 222). En els versos 845-847 es pot llegir: «Falcx, esmerillos e moiseta/ volon que hom en loire meta/ sella carn que es lur reclam». ${ }^{28}$ D'ací es dedueix que moiseta havia de ser algun tipus d'ocell que s'ensinistrava i que, a més, devia ser un falcó petit, ja que es cridava amb el lloure, a diferència de l'astor i l'esparver, que es criden perquè acudesquen a la mà. Aquestes característiques concorden bé amb el falcó mostatxut, perquè encara que el xoriguer és un petit falcó, aquest no apareix com a ocell de caça en els tractats de falconeria i, a més, ja apareix esmentat amb aquest nom -sorigato, soriguier- en altres llocs del poema. Per altra banda, en la mateixa obra, en els versos 1297-1303, l'autor explica les plomes que cal emprar per escatir (empeltar) una ploma trencada dels diversos ocells: «Tersol scantis d'esparvier,/ a mosquet, esmerillo quier,/ a tersolet esmerillo/quier tersolet sorigato/si no potz atrobar moiseta/ o autra pena petiteta» (Schutz 1945: 97, 114). ${ }^{29} \mathrm{El}$ significat d'aquests versos és el següent: el mascle de l'astor (tersol) s'empeltarà [amb ploma] de femella

28 Amb tota probabilitat, en el vers 867 , on es llegeix mosqueta, hauria de dir moiseta, ja que l'argumentació segueix la relació d'aus presentada una mica més amunt. Potser és un error en el manuscrit (fàcil d'entendre, ja que en altres llocs s'esmenta un altre ocell anomenat mosquet) o potser es tracta d'un defecte de lectura de l'editor.

$29 \mathrm{Hem}$ modificat sensiblement la puntuació i la majúscula proposada per l'editor per ajustar adequadament el significat. 


\section{Ricardo M. Olmos de León \& Carmel Ferragud. El Llibre de cetreria del vescomte de Rocabertí}

d'esparver (esparvier), el mascle de l'esparver (mosquet) demana [ploma d'] esmirle (esmerillo), el mascle de l'esmirle (tersolet esmerillo) vol [ploma de] mascle de xoriguer (sorigato), si no pots trobar [ploma de] moixeta, o altra ploma petita. En el present passatge resulta clar que moiseta és un ocell diferent de sorigato, és a dir, diferent del xoriguer. Això porta a sospitar que la moiseta és el falcó mostatxut, que és l'única au de caça que quedaria per esmentar en el poema.

Una volta identificat el possible terme en una llengua pròxima (provençal), hem pogut localitzar, ja en llengua catalana, alguns passatges en els quals s'esmenta aquest ocell. Així, en el poema titulat Lo somni de Joan Joan, del poeta valencià Jaume Gassull (segle XV), llegim (Miquel 1911: 176-177):

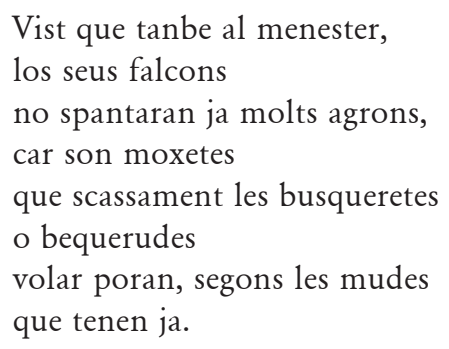

En aquesta ocasió, per expressar la incapacitat dels falcons vells -l'edat es compta per les moltes mudes que tenen- per a capturar els grans agrons, se'ls compara amb les moixetes, que tot just atemoreixen les petites busqueretes o bequerudes. En aquest context té ple sentit que es compare el falcó vell i la seua presa (agró) amb un petit falcó -com podria ser el falcó mostatxut- i les seues preses, que són les aus petites.

Un tercer passatge en el qual es menciona la moixeta és en el Libro tercero de la Crónica de la inclita y coronada ciudad de Valencia y su reino, de Martí de Viciana, publicada en 1563. En el capítol «Del castillo de Culla y su tenencia» descriu una peculiar tècnica de caça en la qual participa la «moxeta» (Iborra 2002: 171-172):

\footnotetext{
En este campo en los meses de julio y agosto, se haze una caça de las apazibles y graciosas que caçadores pueden inventar ni hallar, la qual es de esta manera, que por los pinares de los contornos del campo se crían e buelan por los pinos muchas aves de rapiña a semejança de gavilanes, salvo que son algo menores y tienen un collar negro que les rodea el cuello. A estas aves los moradores de la tierra les llaman moxeta y en el campo en aquellos meses habitan muchos páxaros que son codornizes, cugujadas y otras diversas especies de paxaricos. E quando los hombres quieren salir al campo a caça, llevan algunos perros para que, rastreando, muevan los páxaros. Y en aquella sazón en que los caçadores son en el campo, el uno dellos da bozes y gritos con boz muy llena, diziendo: Ha, ha moxeta! Ha ho moxeta! Ha ho moxeta! E luego le acuden quatro o seis y aun doze aves de las moxetas bolando por los aires, encima y por el endrecho que andan los caçadores y rastrean los perros. E quando algún páxaro del suelo se levanta, la moxeta que le coge, se le lleva y come. Por donde los páxaros cobran tanto miedo de las moxetas, que antes permiten que el caçador las tome o mate que no bolar en alto. [...] E cada vez que los caçadores quieren irse de la caça, buelan un páxaro de los que tienen bivos y aquél se lleva una moxeta. Y después buelan otro para otra. Y assí uno a uno hasta que cada moxeta tenga el suyo.
} 


\section{Ricardo M. Olmos de León \& Carmel Ferragud. El Llibre de cetreria del vescomte}

de Rocabertí

Hem transcrit l'extens passatge pel gran interés que ofereix. Tant la descripció de la moixeta, com l'hàbitat, el comportament parcialment gregari quan hi ha abundància d'aliment i l'efecte que causa en les petites aus dels camps de les quals s'alimenta, assenyalen, sens dubte, cap al falcó mostaxut (Palacín 2014). Per a més confirmació es pot destacar el fet que alguns tractats de falconeria del segle XVI expliquen una tècnica de caça estretament relacionada amb la descrita en la Crònica i que es porta a terme mitjançant el falcó mostatxut. ${ }^{30}$ La diferència entre la tècnica descrita en la crònica $i$ en els tractats de falconeria radica en que en aquella els ocells que atemoreixen els petits ocells dels camps, tant com per deixar-se capturar fàcilment pel caçador, són animals salvatges, mentre que els dels tractats estan ensinistrats i són portats pels caçadors en la mà, en lloc de volar lliurement per damunt d'ells. També resulta molt interessant aquest passatge perquè reprodueix exactament la tècnica de caça descrita per Aristòtil a Tràcia i que erròniament ha estat considerada en alguna ocasió com una mostra del coneixement i pràctica de la falconeria en aquella societat i període històric (Lewis / Llewellyn-Jones 2018; Epstein 1943: 501-502):

In the region of Thrace once called Kedrepolis, men hunt birds in the marshes with the aid of hawks. The men use sticks to flush the birds from the reeds and bushes, making them fly up, and the hawks appear from above and pursue them. The frightened birds then settle back to the ground, and the hunters are able to strike them with their sticks and catch them. The share their catch with the hawks, throwing some of the small birds into the air, where the hawks seize them.

El darrer testimoni que oferim és el més clarificador, ja que confirma explícitament que les moixetes són els alcotanes. Es tracta d'un procés judicial datat entre 1425 i 1428, que es conserva, per atzar, en l'Arxiu Municipal de València, ja que els fets es desenvolupen a Morvedre (Sagunt), i són jutjats pel lloctinent del justícia criminal de la capital. El cas en realitat versa sobre la història d'amor entre Úrsola Vilaroya, casada amb un prohom de Morvedre, i Joan Argent, el mestre que regentava l'escola. En el testimoniatge que durant el judici dona Pere Saïdia, el fill del batle de la vila, s'explica com el mestre li va fer una promesa on rau el contingut que ací interessa: «E lo dit N'Argent promés-li a ell, dit testimoni, de portar sparvers, e tramés-li tres o quatre alcotans alter moxetes» (Díaz 2007: 302). Més enllà de la rellevància d'orientar-nos en la categorització de l'ocell, també es posa de manifest l'àmplia gamma de personatges que estaven interessats en la pràctica de la falconeria. ${ }^{31}$

Hem cregut oportú aturar-nos en la identificació d'aquesta au i la seua localització en les fonts de la Corona d'Aragó perquè es tracta d'un ocell de caça de la falconeria medieval i renaixentista que havia passat desapercebut fins al present $\mathrm{i}$ que en les rares aparicions en les fonts no havia pogut ser identificada adequadament, tan sols restaven els passatges en què es feia referència a aquest animal sense entendre'ls del tot.

30 El capítols es troben en el Libro de acetrería y montería de Juan Vallés (Fradejas 1994: 195) i en els Tre libri degli uccelli da rapina, de Francesco da Carcano (1568: f. 151r-v); en aquesta última obra, la denominació que rep el falcó mostatxut és astorella.

31 Vegeu, al respecte, en aquest mateix dossier, el treball sobre el falcó Galiana de Ferragud, Olmos i Bataller.

SCRIPTA, Revista internacional de literatura i cultura medieval i moderna, núm. 17 / juny 2021 / pp. $237-279$ 


\section{Ricardo M. Olmos de León \& Carmel Ferragud. El Llibre de cetreria del vescomte}

de Rocabertí

A més de les esmentades espècies de falcó, de l'esmirle i de la moixeta, els caçadors de l'Europa occidental van emprar amb freqüència altres dues aus que eren molt semblants entre si, excepte per la grandària. Aquests dos ocells tampoc són esmentats pel vescomte de Rocabertí, però sí que apareixen detalladament descrites al Llibre de caşa (Garcia 2013: 198-204). Cal dir, a més, que la documentació d'arxiu on s'esmenten és molt abundant, i la seua denominació no ofereix cap dubte. La major d'elles era l'astor, ocell present a tot Europa, propi de terrenys boscosos, en els quals es desenvolupa perfectament i construeix el niu. És una au amb grans qualitats per a la captura de preses molt diverses, però el vol de caça, normalment breu, directe i a escassa alçada, no té la vistositat del prolongat i aeri dels falcons en la persecució de la presa, de manera que al llarg de l'edat mitjana s'observa una pèrdua del seu protagonisme entre reis i prínceps, que van adoptar alguns dels falcons com ocells predilectes per a l'exercici de la caça.

Similar a l'astor, però de talla molt menor, era l'esparver. Va ser una au molt preada en l'edat mitjana $\mathrm{i}$ amb freqüència els tractats de falconeria se n'ocupaven detalladament, tant per a descriure-la, com per a instruir sobre el seu ensinistrament i cura de les malalties. En català és el Llibre de caça el que més informació proporciona sobre aquest ocell de caça (Garcia 2013: 197198, 200-208). ${ }^{32}$ A més de les seues qualitats per a la captura d'aus mitjanes i petites, ${ }^{33}$ l'esparver va gaudir d'una fama d'ocell noble, plasmada i transmesa en diverses llegendes (Fradejas 1970; 2002). Va ser, a més, una de les aus apropiades per a les dames, que es delectaven portant sobre el seu puny una au lleugera, però de gran prestigi, i que els permetia fins $i$ tot caçar còmodament guatles $i$ altres ocells.

Finalment, cal assenyalar que el català medieval, a l'igual que altres llengües del seu entorn, va desenvolupar dos termes tècnics específics, prim i tercol, per a designar respectivament els exemplars femella i mascle dels ocells de caça. Malgrat que el seu ús en les obres tècniques conservades no és molt freqüent, el significat és perfectament clar, fins i tot en les traduccions del llatí, que en aquesta ocasió sí que van saber traslladar adequadament el significat i emprar els termes propis dels caçadors de llengua catalana: «Aquest falconer aytal deÿa que ell avia vist moltes veguades que.l prim e lo tersol pares aportaven a menyar a lurs fills en lurs lochs damunt dits de les penyes e de les roques» (Garcia 2021: 308). El Llibre de caça, per altra banda, ens aclareix explícitament el significat dels termes prim i terçol en els capítols dedicats a la descripció dels astors, malgrat que una taca en el còdex impedeix llegir adequadament una

32 Ens referim a la descripció de l'ocell, no als remeis per a les seues malalties, ja que a alguns dels tractats catalans es presenta com a específic per als esparvers, tot i que realment es poden trobar també en altres obres prescrites per a altres ocells.

33 El 31 de maig de 1389, el rei Joan I escrivia: «Sapiats que açí prob de Monçó, a dues legües, ha perdius novelles les quals són ja majors que una gualla e de aquelle nos an ja açí presentades. Per què us manam que, vistes les presents, vingats açí a nós ab lo sparver e ab tots los cans per tal que pugats caçar de aquelles» (Bofarull 1882: 101). Aquest document ens informa del tipus de preses caçades amb l'esparver, perdius joves, i que, a més, aquesta caça es desenvolupava amb l'ajuda de gossos.

SCRIPTA, Revista internacional de literatura i cultura medieval i moderna, núm. 17 / juny 2021 / pp. 237-279 ISSN: 2340-4841· doi:10.7203/SCRIPTA.17.209914 
paraula, que sens dubte havia de ser femella: «Capítol de les condicions e maneres [e volers] que deu haver lo astor prim que és dit fe[rman]iu», "Capítol dels astors terçols, que són dits mascles e són los menors» (Garcia 2013: 198, 200). Aquest últim passatge ens informa, addicionalment, d'una característica molt important dels ocells de caça i ben coneguda pels caçadors en l'edat mitjana: els exemplars més petits de cada espècie són els mascles i els més grans, les femelles, cosa que les feia més preades i valorades per a la caça. Els termes prim i terçol formaven part del llenguatge habitual dels caçadors i queda testificat per l'abundant documentació d'arxiu que els recull: s'ordena que es paguen 385 florins «a n’Anthoni Barbant, mercader de falcons natural del regne Alamanya... per lo preu de $\mathrm{X}$ falcons grifants, ço és, IIII prims e VI terçols». ${ }^{34}$

Hi havia una excepció a aquesta forma de referir-se als exemplars mascles i femelles dels ocells de caça: el mascle de l'esparver tenia un nom propi, moscard, i no es designava com esparver terçol. En realitat, es tracta d'una au diminuta i molt delicada, que només rarament es devia ensinistrar per a la caça, fet que provoca que la seua presència a les fonts siga mínima. Entre la documentació de Joan I es troba una carta en què «demana sis moscarts» (Roca 1929: 297). El DCVB conté un lema per a moscard en el qual transcriu un document del segle XV que menciona aquest ocell («Si degun hom de la vila de Solsona haurà sparuer o moscart e volie anar a caçar»), tot i que no el descriu com el mascle de l'esparver i simplement el defineix com «Cert ocell de rapinya emprat en la caça». Tanmateix, la dificultat per a trobar mencions del moscard en la documentació i altres fonts no vol dir que no fora un terme emprat i ben conegut per la societat, cosa que es dedueix del seu ús en la poesia trobadoresca; només té sentit que el poeta Cerverí de Girona l'emprara en les seues composicions si fora plenament conscient que el seu públic en coneixia el significat i, amb això, poguera apreciar el poema. Així, en la Cançó del moscart, fa referència al tracte que la dama reserva a l'enamorat, i s'hi llegeix (Martín 1994: 520):

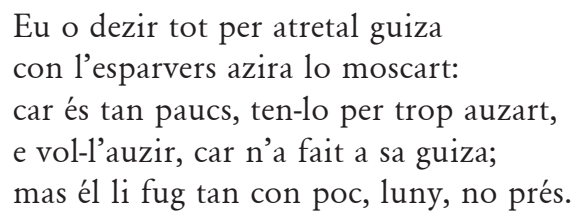

En aquest passatge l'esparver (femella) representa la dama, mentre que el moscart (esparver mascle), el cavaller enamorat. El desconeixement del vocabulari tècnic de la falconeria va impedir a l'autora de l'estudi comprendre adequadament el passatge, per interpretar moscart com 'mosquit', i es va perdre així l'autèntica relació entre esparver i moscard, que són la femella i el mascle de la mateixa espècie.

34 Arxiu del Regne de València, Mestre Racional, vol. 8768, f. 80r-v (28-01-1427). 
Cal assenyalar, per a concloure, que en un dels tractats catalans dependents de la tradició llatina, apareix el terme mosquet per a designar aquesta mateixa au: «Aquest linatge de falcons an senyals en la cara axí com los altres, e an molt longues les ales e-sguardament de son cors, e ha la coha de bona mesura, e les cames he los peus plens de colós citrina, e és manor que esperver, e sa cantitat és axí com un aucell que hom apella mosquet». No obstant això, considerem que en aquest cas la forma proporcionada pel traductor no reflecteix el llenguatge dels caçadors, sinó que simplement és una adaptació de l'original llatí «muscetum», tot i que no es pot descartar que el terme mosquet fora també utilitzat en català en alguns territoris, ja que en una llengua molt pròxima, com es l’occità del poema Dels auzells cassadors, sí que hi apareix (Schutz 1945: 94-95). 


\section{Ricardo M. Olmos de León \& Carmel Ferragud. El Llibre de cetreria del vescomte}

de Rocabertí

\section{Bibliografia}

Bofarull i de Sartorio, M. de (1881) «[Documentos venatorios del] Archivo de la Corona de Aragón», La Ilustración Venatoria, 4, p. 86.

(1882) «[Documentos venatorios del] Archivo de la Corona de Aragón», La Ilustración Venatoria, 5, p. 101.

Bover, J. / Rosselló, R. (2003) La Falconeria a les Balears, s. XIII-XV, Impremta Roig, Campos (Mallorca).

Carcano, F. S. da (1568) Tre libri de gli uccelli da rapina, Venècia, Gabriel Giolito de’ Ferrari.

Cifuentes i Comamala, L. (2006) La ciència en català a l'Edat Mitjana i el Renaixement, 2a ed. revisada i ampliada, Barcelona/Palma, Universitat de Barcelona/Universitat de les Illes Balears.

(2016) «El receptari mèdic baixmedieval i renaixentista: un gènere vernacle», dins Badia, L. / Cifuentes, L. / Martí, S. / Pujol, J. (eds.) Els manuscrits, el saber i les lletres a la Corona d'Aragó, 1250-1500, Barcelona, Publicacions de l'Abadia de Montserrat (Textos i estudis de cultura catalana, 210), pp. 103-160.

. (2021a) «Rocabertí, Jofre (VII) de (Paralada?, c. 1420 - Peralada, 1479)», Sciència.cat DB nom1935 (03 / abril / 2021)

(2021b) «Rocabertí, Jofre (VII) de (c. 1420 - 1479). Llibre de cetreria», Sciència.cat DB op122 (03 / abril / 2021).

Delgado Montoto, M. (2007) Edición crítica del Libro de la caza de las aves, de Pero López de Ayala, Madrid, Calasancias.

Díaz Borrás, A. (2007) Contra Úrsola. Morvedre, 1425-1428. Una aproximación bistórica, Sagunt, Centro Arqueológico Saguntino.

Epstein, H. J. (1943) «The Origin and Earliest History of Falconry», Isis, 34/6 pp. 497-509.

Ferraces Rodríguez, A. (2019) «Un recetario médico altomedieval (Città del Vaticano, BAV, Pal. lat. 1088, ff. 50r-66r): ensayo de edición crítica", dins Pérez Barcala, G. (ed.) "Cui tali cura vel remedio subvenitur". De animales y enfermedades en la Edad Media europea, Avellino, Edizioni Sinestesie, pp. 41-80.

Fradejas Lebrero, J. (1970), «Hidalgo como un gavilán», La Estafeta Literaria, 452, pp. 10-12.

. (2002) «Una leyenda cetrera medieval: el gavilán», dins Fradejas Rueda, J. M. (ed.) La caza en la Edad Media, Valladolid, Universidad de Valladolid/Instituto de Estudios de Iberoamérica y Portugal, pp. 61-77.

Fradejas Rueda, J. M. (1993) «¿Una versión catalana del Livro de falcoaria de Pero Menino?», dins AA.DD. Actas do IV Congresso da Associação Hispânica de Literatura Medieval (Lisboa, 1-5 outubro 1991), Lisboa, Cosmos, vol. 3, pp. 187-190. 


\section{Ricardo M. Olmos de León \& Carmel Ferragud. El Llibre de cetreria del vescomte}

de Rocabertí

Fradejas Rueda, J. M. (ed.) (1994) Juan Vallés, Libro de acetrería y montería, Madrid, Círculo de Bibliofilia Venatoria, 2 vols.

(1998) Literatura cetrera de la Edad Media y el Renacimiento Español, Londres, Department of Hispanic Studies/Queen Mary and Westfield College.

. (2001) «Juan manuel - El Libro de caza», dins Fradejas Rueda, J. M. (ed.) Don Juan Manuely el Libro de la caza, Tordesillas, Instituto de Estudios de Iberoamérica y Portugal: Seminario de Filología Medieval, pp. 127-213.

. (2005) «La influencia del De arte venandi cum avibus de Federico II en el Libro de la caza de Juan Manuel», dins Fradejas Rueda, J. M. (ed.) Los libros de caza, Tordesillas, Instituto de Estudios de Iberoamérica y Portugal: Seminario de Filología Medieval/Universidad de Valladolid, 2005, pp. 41-54.

. (2008) Tratados de cetrería catalanes (siglo XIV), estudi, transcripció i notes de Fradejas Rueda, J. M. amb la col.laboració de Garcia Sempere, M. [i] Van den Abeele, B.; proemi: Condesa de Montagut Alto, Madrid, Círculo de Bibliofilia Venatoria.

. (2012) Juan de Sahagún: Libro de las aves que cazan, <http://www.aic.uva.es/clasicos/sahagun/ sahagun-1.html>

Fradejas Rueda, J. M. / Dietrick Smithbauer, D. (2018) «Recetas breves: microtextos cetreros españoles», dins Doyen-Higuet, A.-M. / Van den Abeele, B. (eds.) Chevaux, chiens, faucons: l'art vétérinaire antique et médiéval à travers les sources écrites, archéologiques et iconographiques, Turnhout, Brepols (Textes, études, congrès, 28), pp. 161-188.

Garcia Sempere, M. (1993) «Els ocells caçadors de la poesia medieval», dins Alemany, R. / Ferrando, A. / Meseguer, L. B. (eds.) Actes del novè Col Voqui Internacional de Llengua i Literatura Catalanes (Alacant-Elx, 9-14 de setembre de 1991), Barcelona, Publicacions de l'Abadia de Montserrat (Biblioteca Abat Oliba, 124), vol. 1, pp. 233-244.

(ed.) (2013) El Libre de caça: estudi i edició d'un tractat de falconeria medieval, [ed. a cura de] - (dir.) Mas i Miralles, A. / Arronis i Llopis, C. / Càmara i Sempere, H., Alacant/Barcelona, Institut Interuniversitari de Filologia Valenciana/Publicacions de l'Abadia de Montserrat.

Garcia Sempere, M. (2021) «El Llibre dels ocells de caça, o Flors de les receptes medicinals per a ocells de caça», Scripta, 17, pp. 280-336.

Iborra, J. (ed.) (2002) Martí de Viciana: Libro tercero de la Crónica de la inclita y coronada ciudad de Valencia y su reino, València, Universitat de València.

Lewis, S. / Llewellyn-Jones, L. (2018) The Culture of Animals in Antiquity. A Sourcebook with commentaries, Abingdon/New York, Routledge.

Lupis, A. (1975) «La sezione venatoria della Biblioteca aragonese di Napoli, e due sconosciuti trattati di Ynnico d'Avalos, Conte Camerlengo», Annali della Facoltà di Lingue e Letterature Straniere, n.s., 6, pp. 3-101. 
Lupis, A. (ed.) (1979) Petrus de l'Astore: edizione critica del trattato di falconeria mistilingue con una traduzione in antico francese dal ms. B.N. 2004, Bari, Adriatica.

Lupis, A. / Panunzio, S. (1992) Caccia e pratica veterinaria a Napoli e nelle corti italiane del Quattrocento, Bari, Adriatica.

Marco, M. (2015) «El Llibre de Fra Bernat: Una rica mostra del lèxic groller i obscè del segle xv», Actes del XVIIè Col loqui de l'AILLC (València, 2015), pp. 125-135.

Martín Pascual, L. (1994) La tradició animalística en la literatura catalana medieval $i$ els seus antecedents, Tesi doctoral de la Universitat d'Alacant.

Mas i Miralles, A. / Garcia Sempere, M. (2013) «Tractat per l'art de la caça: edición y estudio léxico», Reinardus, 25, pp. 96-119.

. (2021) «Tractat de medicina per tots els ocells de caça. Introducció, anàlisi lèxica i edició», Scripta, 17, pp. 337-376.

Melchor Fenollosa, R. (2017) Pratica de citreria: un tractat de falconeria de Maties Mercader (1475), edició crítica, introducció i notes de -, València, Institució Alfons el Magnànim.

Miquel y Planas, R. (1911) Cançoner satírich valencià dels segles xv y ХИ, Barcelona, Biblioteca catalana.

Miralles, Melcior (2011) Crònica i dietari del capellà d'Alfons el Magnànim, ed. de M. Rodrigo Lizondo, València, Universitat de València.

Olmos de León, R. M. (2015) Los cuidados de las aves de caza: estudio de la medicina de las aves a partir de los tratados castellanos de cetrería (siglos XIII-XVI), Tesi doctoral de la Universitat de València.

(2018) «The care of hunting birds in the late Middle Ages and Renaissance according to the Spanish falconry treatises (1250-1565)», dins Gersmann, H-H. / Grimm, O. (eds.) Raptor and human: falconry and bird symbolism throughout the millennia on a global scale, Kiel/Hamburg, Wachholtz/Murmann (Advanced studies on the archaeology and history of hunting, 1), vol. 2, pp. 539-558.

----. (2019) «La cirugía en el cuidado de las aves de caza durante la Baja Edad Media hispánica: artífices, operaciones e instrumentos", dins Pérez Barcala, G. (ed.) "Cui tali cura vel remedio subvenitur". De animales y enfermedades en la Edad Media europea, Avellino, Edizioni Sinestesie, pp. $155-175$.

Palacín, C. (2014) «Alcotán europeo - Falco subbuteo», dins Salvador, A. / Morales, M. B. (eds) Enciclopedia Virtual de los Vertebrados Españoles, Museo Nacional de Ciencias Naturales, Madrid. http://www.vertebradosibericos.org/

Pons, A. (1949) Llibre del Mostassaf de Mallorca, Palma, CSIC.

Querol San Abdón, J. (2003) Materials per a un diccionari històric del català científic medieval: el vocabulari tècnic de l'art de la falconeria, Treball de recerca de la Universitat Autònoma de Barcelona. 
Querol San Abdón, J. (2004) El Llibre de cetreria del vescomte de Rocaberti: edició i estudi d'un tractat de falconeria escrit a la Corona d'Aragó, Treball de recerca de la Universitat Autònoma de Barcelona, Facultat de Ciències.

- (2005) «Materiales para un diccionario histórico del catalán científico medieval: el vocabulario técnico del arte de la cetrería», dins Fradejas Rueda, J. M. (ed.) Los libros de caza, Tordesillas, Instituto de Estudios de Iberoamérica y Portugal/Seminario de Filología Medieval/ Universidad de Valladolid, pp. 137-146.

- (2018) L'art de la falconeria a la Corona d'Aragó durant la Baixa Edat Mitjana: edició i estudi dels tractats escrits en català, Tesi doctoral de la Universitat Autònoma de Barcelona.

Roca, J. M. (1929) Johan I d'Aragó, Barcelona, Institució Patxot.

Rocabertí, vescomte de (1951) Llibre de cetreria compost per lo vescomte de Rocabertí, pròleg de Porter i Rovira, J., Barcelona, Asociación de Bibliófilos de Barcelona.

Rodríguez, I. (2013) El Libro de cetrería (1583) de Luis de Zapata: estudio y edición crítica. Tesis doctoral de la Universidad de Valladolid.

Roig, J. (2014) Espill, ed. d’A. Carré, Barcelona, Barcino.

Schutz, A. H. (ed.) (1945) The romance of Daude de Pradas called Dels auzels cassadors', Columbus, Ohio State University.

Trias de Bes, X. (1996) «El Llibre de cetreria del vescomte de Rocabertí: luces y sombras de un códice catalán del siglo XVI», Anuario de la Asociación de Bibliófilos de Barcelona (1993 - 1994), pp. 21-36. 


\section{Edició crítica}

\subsection{Normes d'edició}

a) Seguim com a norma general els criteris d'edició de la col-lecció «Els Nostres Clàssics» de l'editorial Barcino.

b) Regularitzem l'ús de les grafies $u / v, i / j, c / c$. Reproduïm com a $c$ totes les $c ̧$ amb valor alveolar, i com a $c$ totes les $c$ que apareixen davant de les vocals $a$, o i $u$, en la majoria de casos per falta del traç corresponent.

c) No marquem el desenvolupament de les abreviatures

d) Hem reduït sempre les grafies dobles, tant les etimològiques com les no etimològiques si responen només a un únic fonema:

e) Regularitzem la grafia de la nasal palatal nny, yn o nyn > ny.

f) L'accentuació adoptada correspon al timbre vocàlic propi de la variant oriental, zona d'on segurament prové el manuscrit. Usem l'accent diacrític en els casos que indica la normativa actual i, excepcionalment, en altres mots que poden prestar-se a confusió com: àls (altre), là, llà (allà), sí (aixi), à, é i ém (haver), té (tenir), péra/péres (pedra/pedres), mès (participi de metre), etc.

g) Seguim els criteris actuals pel que fa a puntuació, separació de paraules, majúscules i minúscules, apòstrof, guionet, accent i dièresi.

h) Emprem la dièresi damunt la $y$ en mots com aÿna, constitü̈des. En prescindim en els casos de paraules amb $h$ antihiàtica com tribumfo, jabia, traduhit, etc., també les formes verbals de l'imperfet d'indicatiu com dej̈a, fë̈a, bö̈a etc, ja que es tracta d'un text anterior al segle XV.

i) Representem amb un punt volat la pèrdua d'una vocal en una aglutinació quan no s'hi pot utilitzar l'apòstrof: fa $l s$, que $s$, vostr apetit, etc.

j) Pel que fa a la numeració de les pàgines, apareix entre claudàtors la xifra de la pàgina acompanyada de $\mathrm{r}$ (recto) o v (verso).

k) Transcrivim com a un/una, dos/dues, tres/terça les xifres romanes I, Ia, II, IIa, III, IIIa. Els numerals romans els editem en versals i sense punts ni davant ni darrere.

1) Recollim en les notes a peu de pàgina les particularitats següents que presenta el manuscrit:

- Indiquem els casos de mots que cal ometre (e de] de), mots ratllats (per] te per) $\mathrm{i}$ mots interlineats (mare $\{$ sua\}] mare sua). També corregim errors (reastràs] restaràs).

- Incloem també en les notes algunes recomanacions per a determinades lectures (belles > Llegiu balles). 


\subsection{Edició de l'obra}

\section{[LLIBRE DE CETRERIA]}

[1r] Libre de cetreria compost per lo bescompte de Roquallbertín ${ }^{35}$ per lo reverendíssimo senyor, ${ }^{36}$ lo senyor ${ }^{37}$ cardenal $^{38}$ de València.

En nom de Déu et de la sua beneyta mare la verge Marya, comens lo present tractat fet per mi, bescompte de Roqualbertí, a prechs de don Pedro d'Essa. La present ordinatió és ${ }^{39}$ per l'art de la casa e de tota natura o agres de falcons ${ }^{40}$ ni qual qualitat tenen, ni com los deu hom tractar ni donar a mengar, ni quals són pus avantagats ni més valentes quada falcó segons sa natura requer a qualitat.

\section{[1v][Pelegrins]}

Primo comensaré en los falquons pelegrins, com aquels que són merexedors, et de la gentill qualitat e condició que tenen en totas cosas.

Primerament, ans que ell se pesca, se paxen altres falcons seguint-lo -e d'altra manera de ocells de rapina- de la cosa que ell mata que li van detràs. ${ }^{41}$ Et, si pot, ans se paxerà de cosa grossa que de presa chica. E tu qui l'afaytas, et vol tenir-se gros, que tot quant fa, fa per delit et bondat et non per fam; et vol che tu qui cases, que la guallina ${ }^{42}$ no.s pertisca may del carner, que axí com ell és gentill de ànimo, vol bones viuandes et bons pasts, e no vol tenpre fort com altra natura de falcons.

35 Roquallberti] Roquallbertim ms.

36 señor] $s \mathrm{~ms}$.

37 señor $s \mathrm{~ms}$.

38 cardenal cadenal ms.

39 ordinatió és] ordinatió ms. Aquesta addició i la següent la proposa Lluís Cifuentes en la descripció. de l'obra. Pensem que són necessàries per a fer el text comprensible.

40 agres de falcons] agres $\mathrm{ms}$.

41 Possiblement hi ha una inversió de l'ordre. Una possible lectura seria: «Primerament, ans que ell se pesca, se paxen altres falcons e d'altra manera de ocell de rapina que li van detràs, de la cosa que ell mata».

42 gallina] gal guallina ms. 


\section{$[2 r][$ Taguarots $]$}

Segonament te diré ${ }^{43}$ agre són natura de falcons, los quals són dits taguarots. Són de lur natura valents molt et totes tenen aquests senyales: la persona molt chica, et tots les membres que tenen molt grans segon la persona; et tots los més ${ }^{44}$ tenen lo pennatge roig davant en los pits. E aquests falcons venen de la Barbaria. Són falcons molt ardits et per a tota presa grosa, axí com són grues, ostardes, oques, agrons, et matar tota manera de presa grosa, tan gran és lo ardiment qui tenen. E volen-se tractar a mengar com los desús dits falquons pelegrins.

\section{[Montarins]}

Terserament vos diré de altre agre de falquons, als quals apela hom montarins [2v] et altres dien gentils, los quals semblan molt en la qualitat als pelegrins, qu.és que.s volen tenir grossos et ben temprats. Et totes naturalment los demés són ardits. E aquests tals, si.ls podeu haver nienchs, leugerament se fan ${ }^{45}$ grués si.ls i volen meter a tota presa grosa. Com desús vos he dit, totes naturalment són ardits e valents.

\section{[Grifalts]}

Quartament vos diré ${ }^{46}$ de la calitat et condició que.n tenen los falquons grifalts. Lo falcó grifalt és lo pus gran et major falcó que sia en lo món. És de qualitat de falcó vilà, que lo qui fa, fa ${ }^{47}$ per fam. Et vol.s tenir tostemps en loc fresch, et los pastos qui li doneu, que [3r] sien freschs, ${ }^{48}$ axí com és crestat o cabra o ${ }^{49}$ polls e de aquestes coses senblants. Tan tart com porreu, no.l pescau de moltó, qui és mal past e mal serà per a ells, et los causa far venir aigua en lo cap et moltes altres malaltias. Axí mateix, ells són molt calts de fetge et, si.ls ne voleu tinir sans, usau-los molt sovint de l'aigua de la indívia, et meteu-i dins la dita aigua un poc de ruibarbre, et dau-lo-i ab lo past de quinse in quinsi dias, car ells en lur calitat i pecan molt ${ }^{50}$ en calor de fetge, et, si li usau la desús dicta medicina, lo tindreu sa. Encara, com sabeu, ells venen de terra molt freda et, tan tart com poreu, no.ls [3v] pescau de moltó ni mens de colomb, qui és past molt calt. Et tostemps qui.l pescereu, lo mullau ab la susdicta medicina.

\footnotetext{
43 diré] direm $\mathrm{ms}$.

44 més] Aquest mot no es llig bé.

45 fan] far ms.

46 diré] dir ms.

$47 f a]$ Repetit ms.

48 Es refereix a la complexió freda.

49 cabra o] cabra ms.

50 molt $\mathrm{mol} \mathrm{ms}$.
} 


\section{[Bastards]}

Quintament vos diré dels falcons los quals hom se $\mathrm{s}^{51}$ diuen bastars. Venen de la alta Alemanya, los quals falcons $\mathrm{se}^{52}$ mesclan falcons sacres ab proensals, et qui la femella sia sacra et lo mascle, proensal. Y aquests tals són molt bons et aventagats, y a tart ne ix nigú mal, y són falquons qui no.n són gens delicats, et tots pasts li.s poden donar, com si fosen falcons proensals. Et tots los demés són bons llebreters et bons agroners, ${ }^{53}$ et matan moltes altres casas si.1s i voleu meter.

\section{$[4 \mathrm{r}][$ Sacres]}

Sisenament vos diré dels falcons sacres, qui són dits falcons villans, com los proensals. Y de aquestos n'ixin moltos de bons y de ruinens, et tot quant fan, fan per fam, e non per bontat que tingan. E volen-s ${ }^{54}$ tenir grosos e ben temprats, ab dues o tres picadas de un cor e son curall al vespre. E són falquons qui.ls podeu axí tractar com a proensals, ${ }^{55}$ qui non són gens delicats.

Dels falcons bastards, se volen tenir grossos e ben temprats, com los falquons sacres, e axí los podeu tractar.

\section{[Tunicenchs]}

Septenament $\operatorname{vos}^{56}$ diré dels falcons tunicenchs, ${ }^{57}$ quins falcons són ne quina calitat tenen, ni de qui són bons. Tots són bons llebraters [4v] e bons de perdiu e de altres coses. Volen-se tenir baxos y ben temprats, que.n tot lo que fan, fan per fam.

\section{[Proensals]}

Vuitenament vos diré dels falquons proensals, de quina calitat són, de qui us dic que són lo pus vils e pus dolents del món. Ells són bons de perdiu e de liebra huns dos o tres anys; quant de més mudes són, menys se valen, ${ }^{58}$ e és lo contrari de totes les altres agres de falquons, qui com més va, miliors són e de més mudes són. E volen-si tinir baxos e ben temprats, qui tot quant fan, fan per fam e non per bondat que en ells sia.

\footnotetext{
51 se] fe ms.

52 se] se s ms.

53 agroners] agromers ms.

54 volen-se] volens ms.

55 proensals] proesals ms.

56 vos] vo ms.

57 tunicencs] tunicarchs ms.

58 se valen] valen $\mathrm{ms}$.
} 


\section{[Malalties]}

Ara us diré de totes les malalties que.1s [5r] venen, ne quines medisines an mester, ne quines an mester ésser-los obrades; et de tot l'orden, qui e com los deu tinir et tractar cada falcó com és sa natura et calitat, e, segun l'agre de què és, com se vol manegar ni tractar en lo afaytar e fer lourer.

\section{[Afaitat]}

Ara primerament vos diré del falquó pelegrín, com aquell que és més merixedor. Lo falquó pelegrín, quant lo comensareu a fer lourier, feu-li degolar tostemps sobre.l loure la gallina o poll, e ab asò prendrà amor en lo loure, e axí el fareu bon lourier, que.l falcó pelegrín o gentil, si no és bon lourier e que am lo loure, és molt perilós [5v] de perdre, qui tantos $\operatorname{tiren}^{59}$ e axí.ls perdeu.

Ara novament vos diré de 1 es ${ }^{60}$ malalties qui venen als falcons, ne quines medisines an mester ésser-los donadas et obrades.

\section{[Aigua]}

Ara primerament ${ }^{61}$ vos diré de una malaltia que.ls ve al cap, a qui diu hom aigua de cap. E de aquesta aigua, si no ${ }^{62}$ i proveïu en lo principi, les venen tres a quatre mals; e, si no i proveïu prest, si porian perdre e perden la vista, e açò perquè.s ve a congelar l'aigua en lo cap.

Ara us diré, quant és congelada, quina medesina el fareu per fer-li descongelar la ${ }^{63}[6 r]$ dita aigua. Vós areu suc de regualícia, et dar-li-eu en dos o tres jorns, tan com miga avelana cada volta, e açò ans qui.l pescau duas o tres hores, et açò ${ }^{64}$ la i molificarà. E aprés aureu seufràgia, e cascar-la-eu un poc, e aprés metereu-la en un drapet de li et metereu-la a remolyar ${ }^{65}$ in una poca d'aigua tèbea; et de açò metteu-li en les ventanes. Et dic-vos qui li farà venir en fort punt e açò la i farà lansar tota.

Ara us diré a l'aigua que tenen que non és congelada. Pendreu una poca de mostala e picar-la-eu e mesclar-la-eu ab una poca de mel e fer-n'eu rodolí, axí [6v] com un gra de avelana, e prendereu-

\footnotetext{
59 tiren] tiren tiren $\mathrm{ms}$.

60 de les] dels ms.

61 primerament] primierament ms.

62 no] ne ms.

63 la] Repetit ms.

64 açò] a toter co ms.

65 remolyar] remolayai ms.
} 
ne ${ }^{66}$ la mitat, et fregar-li-eu lo paladar, e asò la i farà lansar. E axí meteix, si voleu que non sia tan fort la medisina, areu una poca de oruga e fer-n'eu lo rodolí desús dit, e axí meteix la i farà lansar. E axí meteix, i és bona una píndola de agari si té gens de la dita aigua en lo ventrell. E axí meteix, si té filandres, hi a sguart la dita píndola e les mata e les fa lansar. Axí meteix, areu rail de silidònia e fer-la-eu neta e raureu-la e meteu-la dos o tres horas en un poc d'oli, fet trosets com una mela pelada, e donau-la-i; e, si té aigua en lo ventrell, [7r] la i farà lansar.

\section{[Filandres]}

Més vos diré de una malaltia en què pequen molt tots los falquons, so és, en los filandres. E ve’ls per duas o tres raons. La primera: se crien ${ }^{67}$ los filandres si lo falcó és ${ }^{68}$ cascat e, si proveïu en lo principi, leugerament se cura, e, si no i proveïu, moltipliquen et mata'ls molt prest.

Ara us diré les medisines que.ls curen e sun molt sperimentades. Dar-los-eu ab lo curall ${ }^{69}$ un poc de safrà e, quan se coverien o són chiques, les mata. Axí meteix, dar-li-eu aigua en què agen bolit faves negres, e mulyau-ne, de la dita ${ }^{70}$ aigua, lo past ${ }^{71}$ de qui.l paxeu. E axí meteix, és bo l'aill, donau-los-ne [7v] ab lo curall; e tanbé hi és bo lo denzell. ${ }^{72}$ Mas dic-vos que totes les medisines que van ${ }^{73}$ detràs lo rave gualesch, ${ }^{74}$ etotes les mata donant-los-netantcom locapdel dit manuvell ablocurall, ecascan-loun poc.

\section{[Pantaix]}

Un.altra malaltia ve als falcons qui diu hom pantaix, que.l ve de sobres de bascar. Et per açò pren femta de homo seca e polveriza-la e passa-la per sedàs de serdes de porc, e talia-les menudes e mescla-u ab la dicta pólvera, ${ }^{75}$ e dona-le-y ab lo past calent, e totes jorns fins a tant qui conegas que.l dit falcó ${ }^{76}$ miliore. Et feu-lo star a la serena fins a tant conegau sia guarit.

66 prendereu-ne] predereune $\mathrm{ms}$.

67 crien] orien $\mathrm{ms}$.

68 és] os ms.

69 curall] cullal ms.

70 dita] dit $\mathrm{ms}$.

71 past] pas $\mathrm{ms}$.

72 Es refereix al 'donzell'.

73 que van] van $\mathrm{ms}$.

74 gualesc, 'Provist de les excrescències anomenades gales'.

75 Sembla haver-hi una confusió amb les cerres de porc, pel fet de picar-les i incorporar-les al remei.

76 falcó] fal ms. 


\section{[Cascament]}

Més vos diré una medisina. Quant lo [8r] falquó és casquat, dar-li-eu pólvera de ben Mesué et dar-li-eu ab lo past calent; i, per quascat que sia, lo guarerà.

\section{[Trencadura de os]}

Ara us diré medisine per tota trenquadura de os. Vós areu de la herba que dien margarita, qui fa lo flor blanca; e piquar-la-eu et dar-la-eu lo suc a beure. Et de la herba piquada posar-li-heu en la trenquadura, ${ }^{77}$ e guarerà en cort.

\section{[Càncer]}

Més vos diré un.altra manera de malaltia que.l ve en la boca, que.s diu càncer. Se no i acorreu prest, les menga tota la boca dintre. Les medisines que y són bones són aquestes: hareu una ploma e, ab la dicta ploma, denegar-li-eu la boca del cànser, [8v] tan com porreu, et aprés metereu-li tinta, e asò fareu per dos o tres jorns, e aprés areu suc de limó, e asò.l guarrà per encarnat qui sia.

\section{[Senyals]}

Ara us diré quins són los senyals ${ }^{78}$ quant conexereu quant lo falquó té filandres. Primeramet, quant lo falcó té filandres, ab lo bech se splugua a la ouera e alt al copró. Et quant són fora del ventrel, lavors ${ }^{79}$ és perilós de morir ${ }^{80}$ se no i proveiu prest. E quant ve en les nits, fix parousoment lo fan cridar -crach crach-, de qui és mester li'n doneu lavors del rave gualesch com desús vos he dit, qui res non és bastant a matar-los com la desús dita medisina. [9r] E guarrà molt perfetament.

Més vos diré com conexereu ${ }^{81}$ qui lo falcó té pantax: qui li veureu seu, qui no.s debatrà. Li veureu bater la ouera e spolsar. Proveiu prest, qui laugerament guarerà ab la desús dita medisina.

Ara us diré com conescereu quant lo falcó té cànser: qui, quant menga, non se envia axí prest lo bocí com acostumava; lavors li comença, per què proveiu in fer-li neta la boca. Et feu-li la desús dicta medisina qui, proveint prest, laugerament guarerà.

77 trenquadura] trequadura ms.

78 senyals] senyal $\mathrm{ms}$.

79 lavors] leno is ms.

80 morir] moru ms.

81 conexereu] onexereu ms. 
Ara us diré de una medisina molt sperimentada. Quant tindreu un falcó qui.l conexereu [9v] qui non menga ab aquella fam acostumada, ${ }^{82}$ e qui no stà sà, vós areu VII o VIII pedretes que sien senes, así com un ciuró, e donau-les-hi, ${ }^{83}$ e veureu quines coses li farà lansar, e sanarà lavors perfectament.

\section{[Poretes]}

Més vos diré de una malaltia ${ }^{84}$ qui ve als falcons en les mans que.s di[u] poretes, e fa'ls unflar les mans e, desota la mà, se fa a manera de un clau. E, si.l voleu perfectament guarir per manera qui no li tornen, ${ }^{85}$ vós li fareu svenar de ans dues les mans e, aprés que u areu tretes, les peretes, ${ }^{86} \mathrm{ab}$ la medisina següent, qui li farà exir los dits claus de tota la mà sens negú dupte.

[10r] Vós areu una casoletta o una oleta, e areu una ceba ${ }^{87}$ blancha, et leuar-li-eu ab un ganivet tot l'ull, en maniera qui y fasan una bona cova dintre. E aprés areu de la pus neta ${ }^{88}$ mantega, e aprés metereu-la dintre la oleta e cobrir-la-eu ab una copertora et, ab pasta, posar-n'eu entorn de la boca per manera que non pusca spirar lo qui és en ella, e portau-la al forn. E, quant conoxereu che sia cuita rahonablement la ceba, traeu-la del forn, e aprés piquau-lo tot ensemps $e^{89}$ feu-ne ungüent e, del dit engüent, untau-li les mans totes jorns al palmell halà on té lo clau, e asò lo y farà exir certament. E lo dit clau és axí com un clavell [10v] de gelofe. E aprés, pux les claus ne sien fora, vós li metreu enpastrís restritius en manera que li sanen los forats de là hon són exits los claus. Et, quant lo dit falquó serà ben sanat dels mans, e per guarir-lo ${ }^{90}$ perfectament, per manera qui no li tornen los dits poretes, lavors lo deven esvenar com desús vos é dit.

82 acostumada] acostuma ms.

83 donau-les-hi] donau-les-chi ms.

84 malaltia] maltia ms.

85 tornen] tornore ms.

86 Es refereix a poretes.

87 ceba] cela ms.

88 neta] nela $\mathrm{ms}$.

89 e] le e ms.

90 guarir-lo] guarit ms. 


\section{[Muda]}

Si vols fer mudar falcons o sparvers o stors, pren $^{91}$ caragols e trenqua'ls un poc les coscles e metles en un sachet de li e penga'l al sol, e met jus ${ }^{92}$ un bací; e aquell-aygua qui caurà dels ${ }^{93}$ caragols sia messa en una copola, e cada volta qui daràs a mengar al falquó, mula-li de aquel-aygua lo past [11r] de què.l paxerau, ${ }^{94}$ e veureu merevelyas. ${ }^{95}$

Et, si vols que.l petnage del falquó sia bianque e bon mudat e gentill, pren VI o VIII prunes verdes colides de l'arbre, e meteu-les en la desús dicta aigua dels caragols.

Altra medisina per fer mudar prest un falcó o tot aucel: pren ubagueres e fes-les sequar e fes-ne pólvera, e de aquella pólvera dona al falcó ab lo past, e mudarà dins un mes.

Per far mudar tost ${ }^{96}$ falcó, pren guales et torra-les e fes-ne pólvera, e dona al falcó ab lomell de carn, e donali-u dues voltes [11v] la sedmana a fi que li’n dones vi voltes lo més.

\section{[Pantaix]}

Per lo falcó que té pantaix, prendràs dels cols blanches e levar les fules, e dels tronchos piqua'ls e fes-ne suc, e prendràs coral blanch e fera'ns pólvora ben molta e ben Cernuda, e mesclar-l'as ab lo dit suc e dar-li-u-as a mengar ab la carn qui li daràs de quatre en quatre dies. Et porta' $1^{97}$ totes dies a l'aigua corrent e, si volrrà beure, asò li farà gran ben. Encara lo faràs dormir a la serena, e asò lo guarrà.

Altra cura per la dicta malaltia: dau-li aygua de indívia a beure, e guarerà, qui provat és.

[12r] Altra quura per la ditta malaltia: prendràs fempta de cabrit petit, e sequar-l'as e fer-n'as pólvora ben cernuda, e dar-li-u-as totes dies a mengar ab la carn, una poca fins a tant sia guarit.

Per falqó o estor qui té pantaix, pren granotas e fer-les netes, e aprés ${ }^{98}$ sequa-les e fes-ne pólvora, e dona al falcó o astor a mengar viII o nou dies, e guarrà sens duptes.

91 pren] prou ms.

92 jus] еjus ms.

93 dels] del ms.

94 paxerau] paxerar ms.

95 merevelyàs] mevelyas ms.

96 tost tot $\mathrm{ms}$.

97 porta’l petall ms.

98 aprés] apr ms. 